

\title{
Ecclesiastes in Drama: A Cultural Reading in dialogue with African Proverbs
}

\author{
Mark S. Aidoo
}

\section{(x)Noyam}

PUBLISHERS

Accra, Ghana 


\section{Ecclesiastes in Drama: \\ A Cultural Reading in dialogue with African Proverbs}

Mark S. Aidoo

Copyright (C) 2020 Noyam Publishers.

ISBN 978-9988-53-916-0

DOI: $10.38159 /$ npub.eb20505

Published in Ghana by

Noyam Publishers

All rights reserved. No part of this publication may be reproduced

or transmitted in any form or by any means, electronic or mechanical,

including photocopying, recording, or any information storage

and retrieval system, without permission in writing from the publisher.

For further information or permission, contact:

Noyam Publishers

P.O. Box 165 La, Accra-Ghana

Contact Number: +233 504305248

Email: publications@noyam.org

Website: www.noyam.org 
THIS COPY IS NOT FOR SALE

I dedicate this book to Mr J. E. Aidoo, my beloved Dad.

(C) Copyright 2020, Noyam Publishers | www.noyam.org 


\section{Acknowledgements}

This book is motivated by a need to appreciate Wisdom Literature as Bible students and to read the Bible poetically. I saw that need in 2009 while studying under Choon-Leong Seow at Princeton Theological Seminary, USA. Thanks so much, Professor Seow, for making a great impact in my life. Drama and poetry has now become part of my life, ministry and teaching.

My father, Mr J.E. Aidoo, has been a special pillar in my studies in African traditions and spirituality. You have done so much for me and words cannot capture the love I have for you. This book is a living memory to your profound knowledge and depth of graces and wisdom.

The book would not have seen the light of the day if not for the incredible contributions of a number of supportive people who have labored with me. Thanks to students at Trinity Theological Seminary, Legon Ghana and ECWA Theological Seminary, Kagoro, Nigeria summer class of 2017 for sharing a lot with me in class. A number of students brought me countless proverbs in Igbo, Hausa, and Yoruba. Let me mention my wonderful friend and student, Mrs Beatrice Otu, who made significant contributions to enrich my Ga proverbs. Edith Agble (who just completed Seminary and is awaiting commissioning into the ordained Ministry) collected a lot of Ewe proverbs for me. What would I have done without you all. I am encouraged at the comments I receive from you always.

Eric Sackey has been my friend since childhood. We always communicate in parables and proverbs. Eric is a great man with incredible thought. I appreciate you.

The Very Rev Dr Kofi Amissah painstakingly read through the manuscript and offered many valuable suggestions. I thank 
you for the help and say you are really a brother. To Rev Professor Jonathan E.T. Kuwornu-Adjaottor, I say thank you for always being an encourager.

To the Almighty God who makes all things possible, I humbly bow and worship for bringing me this far. 


\section{Contents}

DEDICATION

iv

ACKNOWLEDGEMENTS

CONTENTS

vii

PREFACE

ix

ABBREVIATIONS

xii

\section{PART ONE}

ECCLESIASTES AS AKAN DRAMA

\section{PART TWO}

\section{THE CANTATA}

Act 1 - Scene I

Act 1 - Scene II

Act 1 - Scene III

Act 2 - Scene I

Act 2 - Scene II

Act 3 - Scene I

Act 3 - Scene II

30

Act 4 - Scene I

36

Act 4 - Scene II

39

Act 5 - Scene I

42

Act 5 - Scene II

45

Act 6 - Scene I

47

Act 6 - Scene II

49

Act 7 - Scene I

52

Act 7 - Scene II

55

Act 8 - Scene I

59 
PART 3

UNDERSTANDING THE WISDOM OF ECCLESIASTES 67

CONCLUSION 


\section{Preface}

This book seeks to present the book of Ecclesiastes as an Akan drama. It presents a family of seven who always meet every evening to share a common meal. The conversations during the mealtime centers on the words in the book of Ecclesiastes. It shows that Ecclesiastes is written as if there are other voices in dialogue with the author. In the book of Ecclesiastes, the author uses multivalent language, literary devises, and rhetorical strategies to draw home his views. The speeches are poetic, employing the techniques of irony, ambiguity and double-entendre to argue on contradictions and indeterminacy of meaning.

The proverbial sayings in the book of Ecclesiastes further portray the idea that others must join in the monologue as in the case of the use of African proverbs. The aim, therefore, is to highlight the various voices and language, and reflect on them with African voices. The seven voices recognised in the book and captured using honorific names of the Akan of Ghana and set in cantata, which is a play interspersed with poetry and songs. Among the Akan of Ghana, such names are given based on the day of the week one is born. Some names are for females and others are for males.

What I have aimed at in this book is to present an easy reading of a difficult book. I must admit that there are so many who find African proverbs very difficult to grasp. Perhaps I have made the book of Ecclesiastes more difficult. Wise sayings lie at the foundations of African culture and define life, although they are a rich resource for education. The book then discusses the background and message of Ecclesiastes so that the drama can be meaningful. Admittedly, contemporary generations are losing the sense of proverbs and wise saying in daily life. 


\section{THIS COPY IS NOT FOR SALE}

My aim further is to encourage dramatic plays as integral part of biblical studies and theological education. The hope is that everyone should be creative. Creativity is a powerful tool that can be used to communicate the gospel. It has an educational element that comes from the practical to the aesthetic. At lectures, I challenge students to be creative. This became my "fresh" approach to teaching. I expect them to act plays and create poetry. In most cases, the books of Job and Proverbs became appealing to students. I came to realise that I could also do my part and make them sail through Ecclesiastes. That made me write a short play on Ecclesiastes. The play captured visuals, music, dance, and dramatic play. Certainly it enhanced individual experience and the reflections after the play were powerful. Some of the students decided to use dramatic art as part of the sermons especially for the youth ministries.

Teaching biblical wisdom literature can be a very interesting. It is one part of the Bible that is conspicuously ignored, but the most interesting of all if handled very well. I have been surprised that many students have grown to love biblical wisdom as years roll by. In Wisdom Literature as in dramatic plays, our memories heighten. It makes people recall biblical statements and stories with fun. Recalling easily also enhances scripture to be kept in the hearts. Dramatic acts double our potential to share the gospel. It attracts and sinks so well in most kinds of soils that surround the heart. It makes people feel happy and a sense of well-being. They enable people to see the world in different ways. It can be likened to a three-dimensional impressionist painting; an action movie. They may speak to the heart than the mind. Through drama, I have come to appreciate and identify with a new way to understand wisdom. Thanks to my students and my institution for giving me the opportunity to try new pedagogical ways.

By dramatizing the sayings of Qoheleth, I seek to bring African proverbs alongside the voices of Ecclesiastes to make the discourse participatory and fun. The fun from dialoguing with Ecclesiastes can give space for deep thinking. It is equally possible to use humour to make a strong point. Dramatizing helps to show that imitating the steps of the book of Ecclesiastes can bring out the force 
of its message, and the feel of its words in the mind and heart so that all can understand better. Drama and poetry have the ability to bring untranslatability and indescribable words into real life. May I say that the neglect of wisdom is costing the world too much. I do not want to lose "my" heritage. Maybe the reader will also find something in this book and the testimonies can go on.

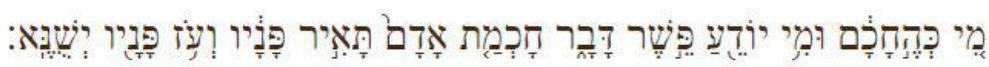

"Who is like the wise person? And who knows the interpretation of a matter? A man's wisdom makes his face to shine, and the hardness of his face will be changed"

(Ecclesiastes 8:1)

Mark S. Aidoo

October 2019 


\section{Abbreviations}

$\mathrm{AB} \quad-$ Anchor Bible

AusBR - Australian Biblical Review

AOTS - Augsbury Old Testament Studies

BBC - Blackwell Bible Commentaries

BS - Biblical Seminar

BSac - Bibliotheca Sacra

BZAW - Beihefte zur Zeitschrift für die alttestamentliche Wissenschaft

CBQ - Catholic Bible Quarterly

HCOT - Historical Commentary on the Old Testament

ICC - International Critical Commentary

JBL - Journal of Biblical Literature

NCBC - New Century Bible Commentary

SJT - Southwestern Journal of Theology 


\section{PART ONE \\ Ecclesiastes As Akan Drama}

Ecclesiastes is one book which looks like someone talking to himself than in dialogue with others. Yet there are many different voices that can be discerned within the single voice of the author. Reading Ecclesiastes as if there are other voices in dialogue with the author is the task worth trying. Bringing the various voices together and how the voices echo within African way of life is what this book seeks to do. This dialogue is what I refer to as drama.

Dramatizing Ecclesiastes is an attempt to offer a cultural reading of the book, and a way of mimicking and capturing the lifethought of the author within the African setting. If the author chose to be philosophical, why should the reader not approach the book from a philosophical perspective? If the author chose to use wise saying, why not respond with proverbial thoughts so that all will be on the same page? One cannot agree more with $\mathrm{H}$. Dhlomo that African drama, like ancient Greek drama, is a combination of religious and magical ritual and a way to imitate what one desires to put across. Nevertheless, it bears a distinct characteristic of inculcating rhythmic dances and song. ${ }^{1}$

It needs to be noted that, in Africa story-telling, plays and dramatic art lie at the heart of communities and predispose the people to their own identity. Drama in African art employs oral narratives as a way to emphasize the community's own history, legends, myths, folklore and social solidarity. The values and significance cannot be overemphasized, for the myths, legends, tales, riddles, proverbs etc.actualize impressions, communicate ideals, comment on public opinion, and entertain. These artistic notations can be an expression of mimetic impulses like dance, and project propaganda and serve H.I.E. Dhlomo, "Drama and the African," English in Africa 4.2 (1977): 3. 
as a mediatory tool. In all these, the experiences of the people play a large role in shaping these thoughts.

The art of oratory is heightened in Africa by the use of proverbs. According to Emile Durkheim, "a proverb is a condensed statement of a collective idea or sentiment relative to a determined category of objects." 2 A proverb does not depend on one person's thoughts or observation; it must be a generally acceptable experience. A proverb, in the words of Lewis Asimeng-Boahene, is a "poetic window on human experience and on local understandings of the world." 3 They have stood the test of time featuring in formal and informal discussions, conversations and activities. Since they are a heritage handed over to the present generations by people of old and are authoritative, they are often preceded such as "the elders say," "my forefather says," "my grandmother said," or "my tribesmen say". In all, a hundred African proverbs are used in the drama (in the form of a cantata).

Dramatic art is essentially a communicative tool; it requires community. Musimbi Kanyaro avers that "Proverbs are like shadow. You have to move with them and they have to move with you."4 The Akan also says, ska enyiwa a, nna w'aka ano (lit. if it affects the eye, it also affects the mouth). Whatever the actor does also impacts on the audience and vice versa. Participation of the audience in art is always required to make drama complete. ${ }^{5}$ The Akan ${ }^{6}$ says, sc ibu $b \varepsilon a$, me so metse $b \varepsilon$ (lit. meaning "if you use wise sayings, I also understand wise sayings"). One wise saying must elicit another to make it complete.

\footnotetext{
Emile Durkheim, Division of Labor in Society (Illinois: The Free Press of Glencoe, 1933), 170.

Lewis Asimeng-Boahene, "Mirror of a People: The Pedagogical Values of African Proverbs as Cultural Resource Tools in Content Area in Social Studies Classrooms," in African Traditional and Oral Literature as Pedagogical Tools in Content Area Classroom, ed. Lewis Asimeng-Boahene and Michael Baffoe (Charlotte, NC: Information and Age Publishing, 2014), 113.

4 Musimbi R.A. Kanyaro, "When Women Arise, The Earth Trembles," in Claiming the Promise: African Churches Speak, ed. Margaret S. Larom (New York: Friendship Press, 1994), 63.

5 M.J.C. Echeruo, "The Dramatic Limits of Igbo Rituals," in Drama and Theatre in Nigeria: A Critical Source Book, ed. Y. Ogunbiyi (Lagos: Pitman Press, 1981), 136.

6 The Akan is not a particular tribe but a language groups in Ghana and La Cote D'Ivoire. They constitute about 40 percent of the entire population of Ghana especially in the south. The major ethnic groups that make up the Akan include Ahafo, Akuapem, Akyem, Anyi, Asante, Assin, Bono, Kwahu, Mfantse, Sefwi, Wassa, and Guan.
} 


\section{THIS COPY IS NOT FOR SALE}

In communication, the hearer must not be taken for granted. It is the communicator's responsibility to decode the message in the way the hearer can understand. When a communicator uses his or her own level of understanding to speak, meaning can hardly be transferred. Communicating to a wise person requires the employment of categories that the wise understands. Good speech in the African setting is where one wise saying encounters another wise saying and a proverb counters another proverb.

A dialogical way of addressing issues using wise sayings can be likened to dancing along with the author. Steps must be taken based on the beat and rhythm but it does not necessarily mean that the rhythm controls all the movements. The movements can sometimes control the rhythm, so the beats can be transposed to meet the tune. As long as African rhythms speak to the dancer and hearer, it must also listen to the dancer and hearers. The dancing analogy used here helps to show that imitating the steps of the book of Ecclesiastes can bring out the force of its message, and the feel of its words in the mind and heart so that all can understand better. John Newport is right in saying that the "power of the stage, whether in comedy or tragedy, is its ability to draw the audience into its action. By engaging people in dramatic conflict, drama stirs people into an awareness of themselves and their world." 7 Dramatic plays thus provide food for thought.

By dramatizing the sayings of Ecclesiastes, I seek to make the discourse participatory and fun. Perhaps the Akan saying $f a b i$ $y \varepsilon$ serew (lit. "laugh over some") may help in capturing the style of presentation. That is not to say that spiritual matters should be taken as fun. Laughter can give space for deep thinking. It is equally possible to use humour to make a strong point. Therefore, laughing over an idea from a scriptural book does not mean that what is under discussion is not a serious matter. Likewise, one needs to allow laughter to take some space especially where things cannot go as one expects. Dramatizing the book of Ecclesiastes and allowing some humor does not diminish one's spirituality. In fact, this is not to suggest, however, that the poetic language of the book has a superior

John P. Newport, “Questions Ministers ask about Literature and Drama,” SJT 10 (1968): 32. 


\section{THIS COPY IS NOT FOR SALE}

tenor. There needs to be a way to find a middle way of reading to arouse some awakening.

The language of drama evokes double meanings, if not triple meanings or more. In dramatic stories, the truth about a character or scene is made clearer when the drama finds its way into the heart. It is in the heart that the revelation and the "truth of the matter", which was made to go through a process of hiding, will be exposed powerfully and evocatively. No wonder that it is known about drama that even though one may have seen it before, experienced it, or actually knows it before the play begins, the "truth of the matter" can come out anew if the act is allowed to sink into the heart. Hence, what has been watched can be watched again. Poets have their own way of capturing the truth. They do so creatively and linguistically. The presentation of a poet enables one to see and feel events from the deepest of the inner worlds so that what is discovered in speech are but overtones of expressions that are hidden to the open world. Drama and poetry have the ability to bring untranslatability and indescribable words into real life.

In terms of putting the book of Ecclesiastes on the screens, Eric Christianson notes the various films that have been influenced by Ecclesiastes. For example: A Fly in the Ointment (1924 [Fr.], 1933 [Fr.], 1943, 1955 [Fr.], 2003[Swed.]); Rejoice in Thy Youth (1939, Swed.); A Time to Kill (1954, 1996); The Sun Also Rises (1957); A Time to Love and a Time to Die (1958); A Time to Live and a Time to Die (1963, Fr.); Pick up on 101 (aka A Time to Every Purpose [1972]); A Time to Die (1982, 1985 [Ital.], 1986); A Time to Remember (1987); Under the Sun (1992); A Time to Love (1999, Ital.). Also, portions of the story in Ecclesiastes has made its way into films like Intolerance (1916), Babette's Feast (1987, Dan.), Darrow (1991), Rembrandt (1936), Gattaca (1997), Final Destination (2000), and Platoon (1986). ${ }^{8}$ Kenneth Morefield has also identified at least 13 films that illustrate some important themes in Ecclesiastes: Forrest Gump; Searching for Bobby Fischer; Roman Israel, Esq.; The Greatest Showman; La La Land; Before Sunset; No Country for Old Men; In Eric S. Christianson, Ecclesiastes through the Centuries, BBC (Malden: Blackwell Publishers, 2007), 83-84. 


\section{THIS COPY IS NOT FOR SALE}

Cold Blood; A Man For All Seasons; Selma; Silence; A Man Escaped; The Man Who Planted Trees. Some movies project positive attitude in life and human endeavours while others do not. Some invite people to consider the diverse nature of life - the emotive aspects of life, the beauty of life, and the underside of life. Some influence real life while others are imaginative yet creative and pedagogical.

Reading Ecclesiastes as drama is like being invited to take a walk. But this is no ordinary walk, for it requires taking calculated steps. I liken it to moonwalking - a dance style that was popular in the late 1980's. It was the late pop musician, Michael Jackson, who stormed the world with his magical steps as if walking on the moon. In moonwalking, the dancer creates the illusion of walking forward in a slow motion by sliding back and forth one foot at a time. A similar feeling can overtake the reader who wants to move forward with the author of Ecclesiastes. A step forward will find one sliding the other foot backwards. Even with such illusory walking, one can go forward with Qoheleth.

Actually, the message presented in the book of Ecclesiastes is dialogical with less dramatic action. The questions and answers in the book, rhetorical as some may be, are heavily loaded with wisdom. The author of Ecclesiastes does not allow the reader to "try and see" in coming up with one's own answers. He offers free advice, but it is in deep reflective statements and questions that require more to understand. It is in these dialogical spaces that one can dramatize the message to help elucidate the meaning of life.

Transferring the biblical story into drama is a way to stir the Christian imagination. It is a way of inviting the reader to participate and allow oneself to be caught up in the dynamism of pessimism and optimism as presented in the book of Ecclesiastes. This dramatic play attempts to use African proverbs to dialogue with the text and support the debate with testimonies and counter testimonies.

Admittedly, contemporary generations are losing the sense of proverbs and wise saying in daily life. Wise sayings lie at the foundations of African culture and define life, although they are a rich resource for education. The Akan says, tsetse wo bi kyere 


\section{THIS COPY IS NOT FOR SALE}

(literally "the past has something to show us"). The difficulty in understanding such rich language puts so many people off. Yet, the values of recapturing proverbs and wise sayings in our post-modern world cannot be overemphasized. This is what this drama has set out to do and the Christian church cannot be left behind.

One may think of the form of drama presented here as an opera than a play. Donald J Grout has clearly shown the difference between an opera and a play, saying:

The difference is one of emphasis. A play centers about the characters and a plot; it may contain episodes which could be omitted without damaging its unity and continuity, but if this is the case, it is, strictly speaking, a defect in the structure. An opera libretto, on the other hand, may almost be said to center about the episodes; at least, it admits and even requires many portions which contribute little or nothing to characterization or to the development of action, such as dances, choruses, instrumental or vocal ensembles and spectacular stage effects. Even the solo songs (arias) are often, from a dramatic point of view, mere lyrical interruptions of the plot; they correspond, in a way, to soliloquies in spoken drama. ${ }^{9}$

Here is drama that has been interlaced with short poems or pictures in episodes. These poems are creative reflections on the book of Ecclesiastes to bring meaning to the meaninglessness. The short poems are not crafted to be metrical. It needs to be noted that Hebrew poetry is not structured in meters. Modern poetry focuses on rhythm but Hebrew poetry does not. In discussing modern poetry, Derek Attridge holds that rhythm plays a key role in biblical poetry and also avers that, "To understand and enjoy poetry means responding to, and participating in, its rhythm - not as one of a number of features that make up the poetic experience, but as the heart of experience. ${ }^{\prime 10} \mathrm{He}$ goes further to explain that rhythm is the heightening and exploitation of language, and language is fundamentally a matter of syllables and stresses. ${ }^{11}$ The beauty lies in how language can be "exploited." The

Donald Jay Grout, $A$ Short History of Opera, $2^{\text {nd }}$ ed (New York: Columbia University Press, 1965), 4.

10 Derek Attridge, Poetic Rhythm: An Introduction (Cambridge: Cambridge University Press, 1995), 1.

11 Attridge, Poetic Ryhthm, 4. Benjamin Hrushovski, however, argues that syllable and stress are not 


\section{THIS COPY IS NOT FOR SALE}

characters in the drama speak different texts, and can speak in various tongues. Diversity is a beauty in Africa, especially in language.

The individuality of the characters is made apparent by the use of traditional names; they are characterised as collaborators. Their identities are imaginative but real to justify their place in dialogue, to interrupt the plot and slow the action. Akan honorific names are used to preserve the identity of the days of the week. That is how Akans give names to a child - based on theday of the week the child is born. In all, the characterisation comes in as a subsidiary to the discussion, actions and emotions.

Reading Ecclesiastes as dramatic art also exploits sound. In his masterpiece, The Art of Biblical Poetry, Robert Alter points out that the "actual sound of biblical poetry will remain at least to some extent a matter of conjecture." 12 He goes on to say that it is not easy to understand the original intentions of the writers and the real nuances of the biblical terms. In most times, there is no discernable style or what biblical scholars commonly allude to a "free rhythm" does not form the basis of biblical poetry. For Alter, the principle of parallelism distinguishes biblical poetry. ${ }^{13}$ Significantly, parallelisms are purposeful, for in biblical poetry the poet/speaker usually select parallel words that call for some particular attention and invite persons to give ear, listen, and more so act on what they hear. ${ }^{14}$ Unfortunately, traditional African proverbs do not pay much attention to sound.

Very little is said about effects, for the intent is to create a voice not necessarily sound. The voice can be entertaining through structure and texture. Cas J.A. Vos says poems consist of three components: (1) structure; (2) texture; and (3) shape or body. The structure is the way the poems are formed like sonnets, love poems, epic poems laments, etc. or in metaphors, repetitions and parallelisms. The shape determines the movement of the "dances" influenced by

enough to make a good poem, neither is meter into a style. See "On Free Rhythms in Modern Poetry" in Style in Language ed. Thomas A Sebeok (New York: The Technology Press of Massachusetts Institute of Technology and John Wiley \& Sons, Inc, 1960), 179.

12 Alter, The Art of Biblical Poetry, 4

13 Alter, The Art of Biblical Poetry, 7

14 Alter, The Art of Biblical Poetry, 12. 
the reading and hearing and makes it possible for people to live by the message. ${ }^{15}$ All too often, scholars claim that Ecclesiastes falls short of structure. It needs to be noted that every structureless design does have a structure. It is possible to ascertain structure in lines that has been drawn haphazardly. In our fast world, everything must come out fast. Frustration usually sets in when it is unsuccessful in finding a structure. So, it is easy to say then that Ecclesiastes does not have a structure. It is believed that it will do so, and time will tell. This drama shades part of the voices of Ecclesiastes to brighten the colours of the structure.

15 Cas JA Vos, Theopoetry of the Psalms (London: T \& T Clark, 2005), 28-37.

(C) Copyright 2020, Noyam Publishers | www.noyam.org 


\section{PART TWO \\ The Cantata}

ACT 1 - SCENE I

(A family of seven siblings sit at dinner to eat)

Abaeku: This is my house but the way I am high, I will spoil the prayer. Who will say a prayer over the meal?

Ebo: Bless us, O Lord!

All: Amen

Asera: Ei, you men and short prayers.

Perba: There you are again, Asera. When we get to your house, say a long prayer and you will see that before the prayer ends, everything will be consumed.

Ntsifor: Let me serve you all. Where is the ladle?

Abaeku: Big mind! You want serve so that you can hide all the fish from all of us and dish it in your bowl. This is our house but I am in charge today.

Perba: But your hands are shaking! How can you serve.

Ayewa: Well, let him serve. I am hungry.

Danyin: Life, O Life! I wish someone would control my life so that 
I don't have to care about anything. That would make me eat till my stomach is upset, dance till my legs cannot carry me any longer, and watch on while young boys deceive the young girls that their love is $993 / 4$ full ... come on, only add a quarter to make it full. Oh, I remember my song.

Cee, cee, see,

Cee I see a sill

Still on a seal

Panting in my heart

Rise to the ceiling

Till I see the sea

Spilling on the seal

And I will be sisi

And I will see.

Cee, see, see

I see the world

In the hands of God

Under the rod

Moving to the left

Turing to the right

What do I see?

If the sea is tight

I will see it right 


\section{ACT 1: SCENE II}

Danyin: Listen to me while you eat. I am the Teacher. I occupy a stool too. My father built for me a great city and my God has blessed me with the divine gift of wisdom. Life is not as it seems to be. Finding meaning to life and all that is done by human beings upon this earth is a sorry business. All is vanity. ${ }^{16}$ Am I not seeing right?

Asera: O, is that so? Isn't it too much wisdom that makes you say so? Some want to have all the meaning to everything but they cannot. Oyiwa! You see how you are running after the wind? As the Akan says, Oba nyansafo wobu no be, wonnka no ascm. ${ }^{17}$

Ebo: If you want to understand life, look at how generations come and another generation is born but the earth is not filled. Yes you are in for trouble. How do you account for generations that die? ${ }^{18}$

Abaeku: Life is like the sun. It rises and it sets. Then it begins the process all again. So is what human beings go through under the sun; the pattern never ends. You are just looking at the sun from the midday forgetting that it had a beginning and it will end. We think we see it yet we do not see it well. Why think you can get some new ideas from where you are standing?

Perba: Life is also like the wind, my friend. You can see it blowing to a direction and you may assume that it is gone but it does not go. If you cannot feel the wind, it does not mean it is not there.

Ntsifor: The Yoruba elders say, Ai le soro ni ibere ori buruku. ${ }^{19}$ When everyone is speaking and I am quiet, it sounds like I do not have anything to say. Life is like the sea that never gets full in spite of all the rivers flowing into it and the rains falling into it. ${ }^{20}$

\footnotetext{
$16 \quad 1: 1-2$

17 Lit. meaning "a wise child is spoken to in proverbs, not in plain language".

$18 \quad 1: 4$

19 Lit. "Inability to speak out is the beginning of bad luck."

$20 \quad 1: 7$
} 
Asera: Aha, then the Teacher is right. No one can explain all things that happen to humanity and come to a logical conclusion. Even under the microscope, the eye assumes that it has seen all things but there is more to be seen. The ear may have heard a lot but there is a lot to be heard. So why feel bored of hearing? ${ }^{21}$

Danyin: So there is nothing new in life. I said it, didn't I? I am not pretending.

Ntsifor: What we see has been there long ago. It was here before our time. ${ }^{22}$

Ayewa: Too much of searching using human wisdom is much vexation but that is what God wants human beings to do. Hmmm all things are transient. Nothing is permanent. ${ }^{23}$

Perba: You have tried to increase in wisdom and knowledge and applied it in life. Did you try madness and folly? I know you did not. You will learn that all is chasing after the wind. ${ }^{24}$

Asera: It is said that much wisdom ends up in much sorrow and more knowledge in more grief. ${ }^{25}$ 


\section{ACT 1 - SCENE III}

Danyin: What then is good and profitable to know? Life O life. The Ga elders say, Ejursfeels le gbehe ewss. ${ }^{26}$ Isn't that true?

Ebo: One who puts aside wisdom is a fool, do not forget that.

Abaeku: And the one without knowledge is ignorant. The problem is people force themselves to get what they do not actually need. The Builsa elders say, Daa chaangtikpieng ale soa nyaala. ${ }^{27}$ That is why God gave everyone two eyes.

Perba: You are wise. Why strive to achieve much wisdom? You are knowledgeable. Why much knowledge?

Asera: It's true my friend. You are what you are. You cannot become what you have to be just today.

Ebo: But you can be what you put into life. The Akan say, Borosuow a गye dew na abaa da ase. ${ }^{28}$

Ayewa: The Ga elders say, $k \varepsilon$ nu tse ye to mli le eshaa. ${ }^{29}$

Perba: The Akan also says, $S \varepsilon$ odupsn tutu a, borosow fifir n'anan $m u{ }^{30}$

Ayewa: Can you verify things you do not understand? It is when you have some little knowledge that you search for more. The Akan also says, nyia oruguar esu nnhu n'akyi. ${ }^{3 l}$

\footnotetext{
${ }^{26}$ Lit. "the generous person often sleeps by the way side." In other words, it is a fact of life that a good person is often mistreated. Being hospitable does mean others can take your place.

27 Lit. "It is not the wide opening of eyes that allows one to see."

28 Lit. "There is always a stick under a pawpaw tree with good fruit."

29 Lit. "If water stays long in a bottle, it goes bad."

30 Lit. "When a big tree falls, a pawpaw tree grows in its place." A pawpaw tree is a soft wood and cannot compete for space with big trees. But the moment the big tree gives way, any soft tree can take its position.

${ }^{31}$ Lit. "The one who is swimming does not see his/her back."
} 
Ntsifor: In fact, life is not as straightforward as you claim. It is said among the Akans, benkum guar nyimfa, na nyimfa so guar benkum. ${ }^{32}$

Ayewa: All the same the Akan elders say, ascm a Nyame edzi esie no, dasanyi nndan no. ${ }^{33}$

Danyin: I have seen good and I have seen bad. Everything that happens on this earth cannot make sense to us because we are human beings. I, the Teacher, rather puts it "meaningless, meaningless." ${ }^{34}$

Asera: So you have heard about it, Teacher! Yes, you were trying to make meaning of life and all that happens on the earth - under the sun. This is where we are. We cannot run from it.

Ayewa: You, the Teacher, say our inability to grasp the meaning of all that happens under the sun does not mean life is useless? The Builsa say: Nuni kan bo nyiam po alaa le nguak ayen noai wongngoa. ${ }^{35}$ You do not have to destroy something that gives you hope.

Abaeku: I agree. Only one person understands what is going on under the sun - the Creator does. Everything is in the hands of the Creator. That is why our forefathers call the Creator borebore nyasabuakwa. ${ }^{36}$

Perba: I understand the Teacher saying that life is transient. But at least, some things are permanent. Maybe we can say emintsimadze. ${ }^{37}$

Ntsifor: Let us set the facts straight. Some things are permanent and some are transient. All these, our finite minds can never grasp the full extent that God has allowed creation to be. Is there anything we can say, 'Look, this is something new?' Ah, Ah. Ah! All this has been

\footnotetext{
32 Lit. "The left hand baths the right while the right hand baths the left." It connotes reciprocity.

33 Lit. "A case which God has settled and shelfed it, a human being cannot overturn it." This means what God has been done is final.

$34 \quad 1: 2$

35 Lit. "A man cannot stand in the river and insult the crocodile that its mouth is long."

36 Lit. "Eternal repository of wisdom"

37 Lit. "From everlasting the same."
} 
since ages.

Ayewa: Then life under the sun is irrational? I was wrong to assume that all is absurd and vanity. But we do not have a long way to go. If we cannot understand things intellectually or control what is going on, let us run to the one who made it so. As long as we have heads, let us use it to find the One. 


\section{ACT 2-SCENE I}

Ntsifor: What is Ayewa doing in the room that she will not come to sit down so that we start eating?

Ebo: It is said, se basia kyer wo dan mu a, nna ahosiesie ntsi $a .^{38}$

Abaeku: So you think she wants to please someone?

Ayewa: I heard what you were saying. I wanted to surprise you people with a hot one before we eat but I cannot find it?

Asera: Do not say you have drunk a full bottle?

Ayewa: No, it is missing.

Perba: Can Ayewa stop all that and say the prayer? We are in her court.

Ayewa: Let us pray:

To you O Lord do we commit this food on our table. As we eat do not let any bone disturb our throat, or the stomach reject any on the meal.

\section{All: Amen}

Danyin: What is the meaning of all this if I am to use my head? What do people gain from all their labours at which they toil? ${ }^{39}$ Is it true that all toil and all skill to work comes from a person's envy of another's achievement? ${ }^{40}$ People work hard, earn some profit, but the profit does not profit them after all. They strive for new things, but soon find out what they got was not new after all. They are never satisfied with the riches. ${ }^{41}$ They try to achieve something, and by the time they get there, they are thinking of something new. I have toiled

\footnotetext{
38 Lit. "If a woman takes long in a room, then she is dressing up."

$39 \quad 1: 4$

40 $\quad 4: 4$

41 $4: 7$
} 
all day and I am going home with nothing. I have been chasing my own shadow. Vanity O vanity! Everything is in vain.

Ayewa: Why do you speak like that? Vanity? Listen, my friend! You cannot say work is meaningless. Work has a purpose and a meaning.

Ebo: It is vanity when you work and deprive yourself from pleasure. To toil without pleasure is a position of the dead. If it happens so, then the dead are more fortunate than the living. ${ }^{42}$ That is to say, to work and not enjoy the benefits you accrue makes you a fool.

Asera: Don't you know that those who are already dead are happier than some who are living? ${ }^{43}$

Ayewa: Unfortunately, the purpose and meaning of work is beyond mortal grasp and full comprehension. Trying to get the full meaning of work is like "chasing after the wind."

Perba: Yes, you have a point. You presume you have caught vapour but when you open your hands, there is nothing. Work is meaningful, but no one can ever have a full grasp of it because it is enigmatic.

Ebo: That is a good explanation. That is why someone cannot beat the chest and speak. We claim we discover things but they have been there for a long time. What has been will be again, what has been done will be done again.

Perba: My elder once said: "If you climb a ladder, you start from the bottom." There is nothing new under the sun. Have you forgotten that nothing is permanent?

Ntsifor: It is intriguing that there is no remembrance of the dead, former thing, and the good work people do; nor will there be any 


\section{THIS COPY IS NOT FOR SALE}

remembrance of things yet to happen among those who come after. ${ }^{44}$

Danyin: I have applied my mind to study and to explore intellectually all that is done under the sun and I will do so again. I have seen all the things that human beings do under the sun. Why did I do that in the first place? That is an unhappy business. In fact, this is a heavy burden God has laid on humankind - to investigate and explore life. But who can fully understand what God wants from us?

Abaeku: There is God who is in heaven. If you can understand what goes on in heaven, you can get to God. That is why our elders say, "A person who fails to listen to his/her elders leads himself/herself to ruin."

Ayewa: You are taking the matter too far. How can one get any idea of heaven? No human being can ever talk of heaven so we cannot talk about God. But God is real and we always enjoy a personal relationship with God. So, God is with us as we live our lives.

Danyin: God created all things and as long as God is good, what God makes is good. No wonder God made all human beings upright. ${ }^{45}$

Ayewa: God has intentionally decided to stay in heaven so that no one can know much about him. In heaven, God is far, remote, and inaccessible to humanity. Therefore, God has made it difficult for us to know what to do. The elders also say, "An individual who does not learn from the parents will be taught by the world." Yes, if you ignore the advice of your Creator, the world will send you to where you do not want to go or dreamed of going.

Ntsifor: In fact, who can fully understand how God rules the world? And God does not make it easy for us to confront Him or to question Him. $^{46}$

\footnotetext{
$44 \quad 1: 11$

$45 \quad 7: 29$

$46 \quad 3: 11 ; 7: 14 ; 8: 17 ; 9: 1 ; 11: 5$
} 
Perba: Life is full of uncertainty. Is that how God made it? However, my grandfather used to say "There is nothing to be ashamed of if one hunts vigorously, but in the end has no catch."

Abaeku: Really! Is that what you think, my friends? God has made so many things available for us. We keep looking too far and expect what has not been given so we hardly see what is before us. That is why we are destroying all that's in our path.

Danyin: What about people oppressing others? That is unfortunate too.

Ebo: Yes, they want to destroy those who are with them. My Akan forefather said, sbra wodan no. ${ }^{47}$ Life is not easy. He also said, sbra tse de ahondze, wosina. ${ }^{48}$

Perba: You may have seen enough but you cannot see more than your grandfather has seen.

Abaeku: My grandmother says, by the time a child thinks he knows, the elderly has already experienced it.

Asera: Do not think beyond what you know. "A chick that will grow into a cock can be spotted the very day it hatches."

Ayewa: The Akan says, Opanyin no tun wo kotskorba. ${ }^{49}$

Perba: Let us listen carefully to what our young friend is saying. Even the Teacher says that life is striving after the wind. I take it that

47 Lit. "Life must be turned." That is to say, taking one position alone is unacceptable. One has to consider other options.

48 Lit. "Life is like beads that must be threaded together." Beads are arranged and threaded together to make it beautiful and useful. Certain beads may not appropriately fit to follow another. The one who is threading the beads must look for a bead that is appropriate in following another. This means that in life there are certain actions that must necessarily be taken at a certain point in time. Doing things anyhow is unacceptable.

49 Lit. "There is a hook at the buttocks of an old person." It means an old person does not easily rise to address every issue. There is something that restrains the old person into taking action quickly. 
people keep deceiving themselves that they have arrived but they haven't.

Ntsifor: What is crooked cannot be straightened, and what is lacking cannot be counted..$^{50}$ One cannot straighten an old tree. The Akan says, akyea, eso emmbu ye. ${ }^{51}$ As long as there is hope there is a way.

Ayewa: The Isoko people say, Ada yan ame te ohere nu, abe gwono uko ake je da $a a^{52}$ What can come will come.

${ }^{51}$ Lit. "It is bent, but not yet broken."

52 Lit. "When you have been totally submerged under water, you don't need a cup to drink water." This saying suggests that a person who is submerged in water will necessarily gulp some of the water. It is not easy closing the mouth throughout while submerged under water for a very long time. That is to say, one can become powerless when caught within certain circumstances. In life, certain things are bound to happen, all things being equal. What can be done is to accept that fact; exploring the meaning of why things happen can be a wild goose chase. 


\section{ACT 2 - SCENE II}

Danyin: Thank you. Just explain this to me! Is pleasure good? Is laughter good? Is striving to be wise meaningful? O, life is short. What is good for people to do under the sun during the few days of their life? ? $^{53}$

Ntsifor: Let me add to what you are saying. I have seen someone who built houses and nice gardens with fruit trees. ${ }^{54}$ But what are all these for if not for pleasure.

Ebo: I have also seen someone who had lots of slaves to serve him. He also had lots of flock, more than everyone. ${ }^{55}$ Why should such a person lack pleasure?

Asera: I likewise have seen someone with lots of money and having many wives. ${ }^{56}$ So should such a person not enjoy, it is strange and senseless.

Abaeku: To have all these and not enjoy is vanity. Why should one find strength only in gaining more in life? ${ }^{57}$

Ntsifor: An Igbo elder once said, nwa aturu chora ipu mpi, ekwo si $k w a$ ya ike. ${ }^{58}$ One must know what is ahead before making a move.

Ebo: What about those who spend all their life studying, looking for wisdom over folly. They forget that what happens to a fool also happens to the wise person. ${ }^{59}$

Perba: Do not say that wisdom and foolishness is the same. Wisdom is like light and foolishness is like darkness. One dispels the other. ${ }^{60}$

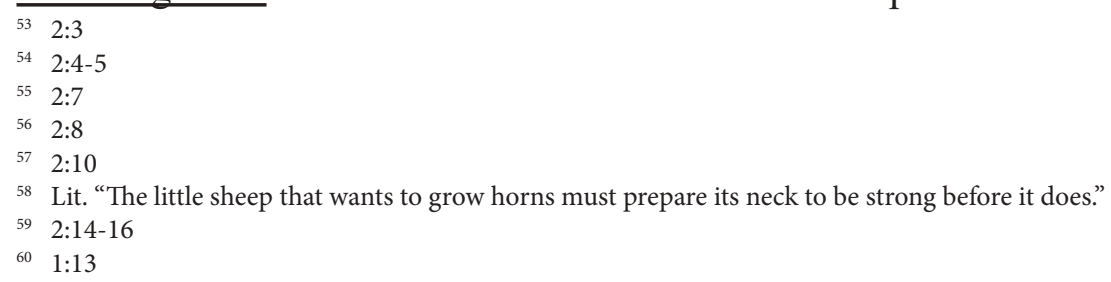


Danyin: These questions about what is good are not easy to answer. Everything in the world seems relative. To some people, life is enjoyable and they take pleasure in laughter and pleasure. To others, life hardly offers them an opportunity to have pleasure. And no condition is permanent. The Akan says, Kyinnkyinn sossıs, səosว kyinnkyinn. ${ }^{61}$

Ebo: Pleasure is meaningless, for what does it accomplish? Laughter is madness. Why should someone laugh out loud and some laugh softly? Drinking wine is also like embracing folly. How can one be sure that wine is good for people to drink? ${ }^{62}$ Our elders say, "It is the calm and silent water that drowns a man." ${ }_{63}$

Danyin: Are you all talking about me? For it is said, "A wise man who knows proverbs, reconciles difficulties." Just last week, I lost all that was in my savings for no reason. I have built houses, planted vineyards and beautiful gardens. I bought many slaves. I owned many livestock. I amassed so much money for myself. I hired many good musicians to sing to my amusement. Yet, when I sat down and thought through all I have done or achieved, I saw that nothing was really worth life. I am just like the poor at the end of the day. Everything was meaningless ${ }^{64} \mathrm{Ah}$ ! Is there anything that might have influenced this?

Ntsifor: Really? There is no advantage for you. Is that why you say everything is meaningless? People have eyes in their heads, yet choose to walk in darkness. Like the fool, the wise man must die.

\footnotetext{
Abaeku: Life is crooked. My Akan forefather used to say, Kwan war den ara, owie abobowano. ${ }^{65}$

${ }_{61}$ Meaning, "What goes around, comes around."

$62 \quad 2: 1-3$

63 Silent waters are usually dangerous because one can hardly know if the undercurrent is swift or slow. In most cases, the undercurrent of waters where the surface looks calm causes people to drown.

64 2:1

${ }^{65}$ Lit. "No matter how long a road is, it ends at the doorway." This suggests that there is always an end to everything. Every pathway leads to a particular destination, and that destination has an entrance.
} 
Ebo: Me too my Akan grandfather says, Kwan tsia ye mbusu. ${ }^{66}$

\begin{abstract}
Abaeku: Listen! The teacher always say, "Whoever loves money never has money enough; whoever loves wealth is never satisfied with his income."
\end{abstract}

Perba: Have you forgotten that it is said, "What is twisted cannot be straightened; what is lacking cannot be counted!"

Ayewa: Folks, the elders say, "when the fool is told a proverb, its meaning has to be explained to him." How can we help the young woman to have answers to all that there is?

Perba: In all, there is nothing better for a person than to enjoy life. We have to eat and drink and find enjoyment after toiling and gaining many possessions. This is what God expects. This is from the hand of God. That's the will of God for humanity. Sometimes we worry ourselves too much. Well the Builsa elders say, suom a dan kan nya bu dek chagiya, bu kan nyini kampuuring ninga ${ }^{67}$

Abaeku: After all it is God who gives wisdom and knowledge to the one He pleases. It is God who gives riches to the one He pleases. God also allows people to enjoy. There is no need to strive under the sun. Enjoy my friends if you have the opportunity, because it is not easy to understand why one is given the opportunity and another deprived of it. ${ }^{68}$ My Ewe grandmother says, odo megbea kana $0 .{ }^{69}$ Let me sing to you a song. Where is my guitar?

\footnotetext{
66 Lit. "Short cuts are dangerous."

67 Lit. "When the rabbit does not see itself well, it will not go out to an open field."

68 2:24-26

69 Lit. "The hungry belly does not refuse the least that has been offered to it." This means one must be grateful for the little that comes.
} 
Life, O life

See how we dramatize life

what is life?

Is it the way I live?

Where is life?

Is it where I go?

How is life if I am somebody?

The way I feel?

Life, O life

Somewhere in breath unknown

Like the riffle

In the hands of a fool

Where can you hide?

Booms where there is

In the hands of a child

The manner God wants all to see life

O my riffle,

Don't smirk the rich

Don't shove the poor

Don't snub the old

Don't scowl the young

Not poh, poh,

Or ho, ho,

But yeh, yeh.

for God's gift of life is rough 


\section{ACT 3 - SCENE I}

Ebo: You are all welcome. I cherish it when we meet as a family every evening for a meal. As custom demands, we have to start our meals with a prayer. Yesterday when we were at a place, he could not pray?

\section{Abaeku: Do not bring yourself!}

Perba: He is not talking about you. Why take it for yourself.

Ntsifor: The elders say, ekutsia biara nyim ne wura. ${ }^{70}$

Abeaku: When I want to react, you people will not allow me. Ebo likes that.

Ayewa: The soup is getting cold.

Ebo: Let me say it.

May God bless the one who grew the foodstuffs, the cook, and the one who has opened his house for us this day.

\section{All: Amen}

Danyin: I have another question. I have toiled under the sun, and fate has made it that I leave everything I have toiled for someone. Who knows whether the person who inherits my property will be wise or foolish? In fact, the one to inherit me may have not toiled at all. This is a great misfortune. So, everything is not as it seems? Vanity, O vanity!

Asera: That is why a person can do nothing better than to eat and drink and find satisfaction in their own labour, celebrating life as a gift of God. For everything we do without God cannot end in real enjoyment. ${ }^{71}$

${ }_{70}$ Lit. "Every insinuation is directed at a particular person." 
Ebo: God is the One who gives us all that we possess and God can cause someone to inherit from us.

Perba: The person who pleases God attains wisdom, knowledge and happiness, but to the sinner God gives the task of gathering and storing up wealth only to bequeath it to another who pleases God to enjoy them properly. ${ }^{72}$

Ntsifor: Meaningless, O meaningless! Do you think God is trying to bring confusion in this world? Or you think there is no moral order at all? Not that life is vain at all. Rather life has its puzzles. Unfortunately, human beings do not know the right answer to fill all the puzzles.

Perba: The Isoko people say, Ero ye evwo vughe ikara ro vo'hwo euun. ${ }^{73}$

Ayewa: In fact, let us not forget a basic fact. There is a time for everything, and a season for every activity under the sun:

a time to be born and a time to die;

a time to plant and a time to uproot;

a time to kill and a time to heal;

a time to tear down and a time to build. ${ }^{74}$

Perba: Yes, there is a time to weep and a time to laugh;

a time to mourn and a time to dance;

a time to scatter stones and a time to gather them;

a time to embrace and a time to refrain from embracing. ${ }^{75}$

\footnotetext{
$2: 26$

73 Lit. "How your eye judges the corn cake will determine if it can satisfy." This suggests that when you imagine that something is good from afar, one can at least enjoy it when it comes near. But when one imagines that something is not good from afar, no matter how good it may seem when it is brought near, it would not bring the satisfaction it is supposed to present. That is to say, some people judge things by its outward appearance and such judgments can lead them to draw conclusions. How one judges with the eyes is important, but how one verifies things matter a lot.

$74 \quad 3: 1-3$

$75 \quad 3: 4-5$
}

(C) Copyright 2020, Noyam Publishers | www.noyam.org 
Ebo: Let me add that there is a time to search and a time to give up; a time to keep and a time to throw away;

a time to tear and a time to mend;

a time to be silent and a time to speak. ${ }^{76}$

Abaeku: And I will say there is a time to love and a time to hate; a time for war and a time for peace. ${ }^{77}$

Ntsifor: That is why the Igbo people say, Ejighi ihe eji agbo $n$ anti agba na $m i .^{78}$ Every pot must have its own ladle.

Danyin: Too much philosophical talk cannot put money into my pocket. Much dreaming and many words are meaningless. If there is time for everything, then what is my right time to know all things? Do I have control over the right time?

Perba: Yes, we are affirming human limitations in terms of time. God makes everything appropriate in its time. Paradoxically, it is not easy to know the right time. We search and search unending. In fact, 'God has made everything beautiful in its time. God has also set a desire for that which is beyond time in the human heart; an impulse leading beyond that which is temporal. ${ }^{79}$

Abaeku: Unfortunately, every human being cannot grasp the totality of existence or find out what God has done from the beginning even to the end. No one is able to establish the divine programme of the world. ${ }^{80}$

Ntsifor: If God has made time this way, then we have to revere him. ${ }^{81}$ Human abilities are not final.

\footnotetext{
$\begin{array}{ll}76 & 3: 6-7\end{array}$

$77 \quad 3: 8$

78 Lit. "We do not employ what we use in cleaning the ear to clean the nose."

79 3:11-12

$80 \quad 3: 11$

$81 \quad 3: 14$
} 
Asera: Do you mean to say there is a time to discern the right time? Know that God has intentionally not given humanity the awareness of the right time. God has set eternity in the hearts of humanity so that we cannot know the opportune time. This is the kind of God we have.

Perba: The Preacher says, as no one has power over the wind to contain it; no one has power over the time of their death. ${ }^{82}$

Abaeku: That is why we have to be happy and do good while we live. That is why I eat well and find satisfaction in the life I lead. ${ }^{83}$ Never blame God, but enjoy the little time God has shown us.

Ebo: Notwithstanding, whatever God does is for our own good and it will endure forever. ${ }^{84}$ How can we have consciousness of the future? It is the Akan who says, sekan tsia noara gye noho wo abofra nsamu. ${ }^{85}$

Ayewa: Young man, haven't you heard the elders say, "By the time the fool has learned the game, the players have dispersed?" Why should one search endlessly for that which is beyond human grasp and forgo what is freely given. Enjoyment is not something to seek but something to receive with a thankful heart. It is entirely appropriate because God has granted it to humanity as their portion and authorized us to use that privilege.

Ntsifor: My Hausa grandfather say, Abinei wani, gubar wani. ${ }^{86}$ One man's meat is another man's poison. I remember my song. Give me

$82 \quad 8: 8$

$83 \quad 3: 13$

$84 \quad 3: 14$

85 Lit. "A Sharp knife knows how to release itself from the hands of a child." Since a child is not very careful in many ways, the sharp knife will cut the child and that would make the child leave the knife.

${ }^{86}$ Lit. "What is bad luck for one person is good luck for another." This proverb suggests that every person is unique and preferences differ. Life is structured in such a way that as one situation goes bad for an individual or group, it paves the way for another situation to go well for another. What someone has used and rejected can be exactly what another needs badly. The writer of Ecclesiastes, however, believes that God may cause bad things to happen to good people yet that could be an open door for blessings to another. 
the guitar.

Time, time, time, This is my time

Don't look around

I will book my pound

Yesterday my time

Dancing in my mine

Saving all my dime

Spending all my heart

Tomorrow will come

To my woes I laugh

Now is my time to gulp

Like springtime in my cup.

Oh, tomorrow is not mine

If I have no time

Saving my life now

All will be my hope 


\section{ACT 3 -SCENE II}

Danyin: What a long prayer! Can anyone really say he or she knows if a bone will not disturb the throat for sure? After all, knowledge is like striving after the wind to catch it. I have heard the elders say, kosi a nnkosi, koda a nnkoda. ${ }^{87}$

Asera: I know three things for sure: First, I know that there is nothing better for people than to be happy and to do good while they live. ${ }^{8}$ Second, I know that everything God does will endure forever; nothing can be added to it and nothing can be taken from it. God does it so that people will fear him. ${ }^{89}$ Third, I know that it will go better for those who fear God although a wicked person who commits a hundred crimes may live a long time. ${ }^{90}$

Ebo: There are two things fools do not know. The first is when a fool does not know that he or she is doing what is on the wrong. That is miserable. Second, fools do not know that they are toiling in vain especially when they do not know the way to a town. ${ }^{91}$

Ntsifor: It is the foreigner who gets lost during the gathering of the kinsmen. And the Ewe elders say, Kpodome xaxe tola metsria yiyido lolo $0 .{ }^{92}$

Perba: So, guard your steps when you go to the house of God. Do not go near pastors who ask you to offer unacceptable sacrifices. Go there to listen rather than offer the sacrifice of fools. ${ }^{93}$

Asera: What you are saying reminds me of the Akan saying, $S \varepsilon$ basia

\footnotetext{
87 Lit. "You try to make something stand and it will not stand; try to make it lie and it will not lie." That

is to say, whatever one does is not acceptable.

$88 \quad 3: 12$

89 $3: 14$

$90 \quad 8: 12$

$91 \quad 10: 15$

${ }_{92}$ Lit. "He who passes through narrow lanes cannot avoid being covered with cobwebs."

$93 \quad 5: 1$
} 
rutu mbirika na se osuo n'enufo mu, onnye dec sbetsew ntsi a. ${ }^{94}$

Ayewa: Any way, do not be quick to make a vow to God in your heart or to pronounce a vow in words. Remember that God is in heaven and you are on earth. So, let your words be few. ${ }^{95}$ The Akan says, ano pa ma adze kye owura. ${ }^{96}$

Ntsifor: It is many words that mark the speech of a fool..$^{97}$ The Isoko people say, Aka ria aa, avwe ako ghara aa. ${ }^{98}$

Perba: Let me add that there are three things some do not know: First, who knows what is good for a person in life during the few days of life. Second, who can tell what will happen after everything is gone? ${ }^{99}$ Third, who knows what is coming or can tell someone else what will happen after one thing happens? ${ }^{100}$ The Hausa people say, Ta yaro kyautake amma bata karko. ${ }^{101}$

Ebo: My Ga forefather says, henskwemo jeee yakagboms feemっ ${ }^{102}$

Ayewa: This reminds me what the Isoko people say, Ogbone je gaan eye aye da reyo'obo vwo yor 'ivie. ${ }^{103}$

Danyin: I have seen how the oppressed are crying with tears and

${ }_{94}$ Lit. "when a woman is running and holds her breast, it is not because it would tear off."

$95 \quad 5: 2$

96 Lit. "A good mouth will see the light of the day." That is to say, those who utter prudent speech will not fall into trouble. They are sure to see the day dawn upon them. The one who speaks unwisely will be locked up and will not see morning light.

$97 \quad 5: 3$

98 Lit. "If you will not eat, do not divide it with your teeth." Putting something in between the teeth can be taken as eating, because a small amount will go through the throat.

$99 \quad 6: 12$

${ }^{100} 10: 12$

${ }^{101}$ Lit. "Knowledge with experience gives good results."

${ }^{102}$ Lit. "Being circumspect does not mean you are a good for nothing fellow."

${ }^{103}$ Lit. "when the race gets tough, a woman holds her breast to run." It draws from the fact that women feel uncomfortable when their breast pound on their stomach as they run with no support. It can be distractive. When the race gets tougher, the runner must put in all the effort to run fast. But since the breast lift itself and falls as one springs on the feet to take strides in an uncomfortable manner, the attention on the breast may cause one to run slower. That is to say it is better to address all that prevents smooth movement before embarking on a venture. 
there is no one to comfort them. It is as if the dead are happier than those of us who are still alive. Which one is better - to be dead or to be alive? ${ }^{104}$ My Mossi great grandfather says, Bi song ya ned biiga; bi yoog yaa a zagl biiga. ${ }^{105}$

Asera: Never try to chase the wind to catch it. People will think you are one of them.

Ebo: Fools fold their hands and ruin their lives. Better is one handful with tranquility than two handfuls with toil. ${ }^{106}$ The Hausa people say, Da rarrate akam taka. ${ }^{107}$

Abaeku: There is a Bena proverb which says: pe wisaka ubitile kyang'ani gende vwiyena, pe wisaka ubite pawutali ugende navangi. ${ }^{108}$ Why think about what is happening to others when there is so much before you now to consider? Life must be lived to its fullest.

Danyin: Let me add this! I have seen a man who is all alone, he has no brother or sister, child or relative. Yet he is working hard. Who is he toiling for? Who will inherit him? ${ }^{109}$ This too is meaningless.

Ayewa: Yes, but two are better than one, because they have good return for their labour. If either of them falls down, one can help the other up. ${ }^{110}$ The Akan say, huw m'enyi do ma me ntsi na otwe nam ebien ebien. ${ }^{111}$

Ntsifor: I pity anyone who falls and has no one to help lift him or her

\footnotetext{
104 4:1-3.

${ }^{105}$ Lit. "I good child belongs to all; a bad child belongs to someone." People want to associate with good things and not bad things.

106 4:5-6.

${ }^{107}$ Lit. "Life is stage by stage."

${ }^{108}$ Lit. "when you want to go fast, go alone; but when you want to go far, walk with others."

$1094: 8$.

110 4:9-10

${ }^{111}$ Lit. "The antelope walks in twos so that when dust enters one's eyes, the other can blow it out."
} 
up. ${ }^{112}$ And it is said among the Akan, sigya ye mbusu. ${ }^{113}$

Ebo: The Akan says, Se tekyerema fir mogya a, wotow bi gu na women $b i^{114}$

Abaeku: Listen to what our forefathers say: a single person cannot use his hand to cover the eyes of God." Again, my Akan grandmother says, dua kor gye ehum a, obu. ${ }^{115}$ Our elders also say, "It is the fool who judges people by the presents they give him."

Asera: Moreover, if two lie down together, they will keep warm. But how can one keep warm alone? ${ }^{116}$

Ayewa: That is why in Swahili it is said, Kidole kimja hakivunji chawa. $^{117}$

Ebo: Even though one may be overpowered, two can defend themselves. A cord of three strands is not quickly broken. ${ }^{118}$ The elders say, when you take a single broom, it can be broken easily. But when the broom is bound together, it is difficult to break.

Perba: It is also said among the Akan, nycnko bon ntsi na kots nnyi tsir. ${ }^{119}$ Again show me your friend and I will show you your character. Woe unto the one who takes a bad friend just to avoid loneliness. Woe to the one who falls into the hands of a wicked woman just because he wants to keep himself warm.

$1124: 10$

${ }^{113}$ Lit. "singleness is a curse"

${ }^{114}$ Lit. "If the tongue bleeds, you spit some out and you swallow some." That is to say not everything is bad.

${ }^{115}$ Lit. "If one tree alone stands in the way of a strong wind, it breaks." That is to say, the strength of two is better than one.

116 4:11

${ }^{117}$ Lit. "One finger does not crush a louse."

$118 \quad 4: 12$

${ }^{119}$ Lit. "It is because of a bad friend that the crab does not have a head." There is a folklore that starts by saying that the crab used to have a head. It was his friend who revealed his secret for him to lose his head. Friends can cause serious problems so one has to be careful with them. 
Ntsifor: Oyiwa! A wicked woman ... hmm. As for this, you are certainly wrong about women.

Ayewa: Men, O men! When will they see something good in women? Do not ever say that about women. Although the Yoruba elders say, Oro obinrin ko se tele, ${ }^{120}$ that does not mean all women cannot be trusted.

Asera: Aha! The man who is not successful in his own marriage does not have any good advice for the younger generation. You think God created you to be an island to yourself? Look around you and see the many possibilities to make friends, build families and build communities. Even when the fatherless cries that there is no one else, the cry is for others to hear.

Abaeku: My Builsa great grandmother say, Nipok waai ate faa yaali la, finfisa kan nyungi. ${ }^{121}$

Ebo: In life, it is better to be a poor but wise young man than to be an old butfoolish leader who no longer knows how to take warning. ${ }^{122}$

Ayewa: It is those who rise from nowhere to be somebody or those who are born with a silver spoon in their mouth that hardly take warning. Isn't is so? And have you not heard that a thousand friends cannot erase the harm done by one enemy? Beware of enemies.

Abaeku: Yes, such foolish leaders may have spent their youthful days in bad places yet does not learn from it. They may have come from prison to be leaders. Others may be born into poverty yet rise into leadership. ${ }^{123}$ All need to learn their lessons. It is said that if you are very hungry, you do not eat with two hands.

\footnotetext{
${ }^{120}$ Lit. "It is not wise to follow the advice of a woman."

${ }^{121}$ Lit. "When you love a woman and she farts, it does not smell."

122 4:13

$1234: 14$
} 
Ebo: That is why the Ga elders say, Ake hinmeii enyo $k w \varepsilon \varepsilon \varepsilon$ to $\mathrm{mli}^{124}$ I have a song to sing. Take the guitar, Perba.

One can love the more

One can hate the more

One can do the best

And better the best

But waiting for the rest

When there is no rest

Then two are better than one

When I lie in bed

When I sit to stare

How much do I pay

When I take a step?

How much do they pay

When nothing is but joy

Two is better than one

Why walk along

When God with me I'll run?

Like a double portion

What my hope will be

Rejoice! rejoice!

I know who I am

So, two is better than one.

${ }^{124}$ Lit. "You do not look inside a bottle with two eyes."

(C) Copyright 2020, Noyam Publishers | www.noyam.org 


\section{ACT 4 - SCENE I}

Asera: Since we are all set, I want to say the prayer over the meal.

Perba: What fish did you use today? It smells like catfish.

Ayewa: We want to pray first, Perba! What is your problem?

Ntsifor: You these women! A simple question and you are at our throat?

Ebo: But we have to pray first before all questions about the food?

Abaeku: Can you all be quiet so that Asera prays over the food?

Asera: O Great One who has given us the opportunity to have some. Bless this family as we eat together.

\section{All: Amen}

Danyin: Please tolerate me and my questions. I chose to worship God and now I cannot do what I like. Why is God like that after all? It is my own money and I can choose to give part to God or not.

Ntsifor: No, you have to be careful. Do not be quick with your mouth to say things you do not mean. Do not be hasty in your heart to utter anything you are not sure of. God is in heaven and you are on earth so let your words be few. ${ }^{125}$

Ebo: When you make a vow to God, do not delay in fulfilling it. For God has no pleasure in fools who make a vow and do not fulfil it. ${ }^{126}$

Perba: Then it is better not to vow at all if you know you will not fulfill it. It is better not to pledge your commitment to God if you are not ready. 
Abaeku: Do not let your mouth lead you to sin. Never say, my vow was a mistake. ${ }^{127}$

Ntsifor: Remember that when the labourer is praised, his cutlass begins to cut more keenly.

Perba: Whoever loves money never gets enough. Whoever loves wealth will never be satisfied with how much income he or she has accrued. Isn't it so?

Ntsifor: I have seen how the rich gain plenty but cannot use them. Rather those who flock to his house are always consuming everything. So what benefit is it to the owner except to feast the eyes on his money and wealth?

Abaeku: Yes, in life the moment you are rich, the food you eat changes. But soon you will be advised to reduce eating and drinking. Hahahahahaha.

Ayewa: Some people work hard but it is difficult to measure how hard the work is. It is the Akan who says, Enyi ber a onnsっ gya. ${ }^{128}$

Abaeku: Listen to this! Laziness leads to a sagging roof; idleness leads to a leaky house. Hence in Swahili it is said, Samaki mkunje angali mbichi, akikauka atavunjika. ${ }^{129}$

Ntsifor: As goods increase, so do those who consume them. ${ }^{130}$ Many visitors will always be at your doorsteps to help you consume your profit. Be careful they do not pounce on the capital.

Perba: The sleep of a labourer is sweet, whether they eat little or much. But as for the rich, their abundance permits them no sleep. ${ }^{131}$

\footnotetext{
${ }_{127}$ 5:6

${ }^{128}$ Lit. meaning, "The eyes can be red, but it will spark fire." The red eye is symbolic of seriousness.

${ }^{129}$ Lit. "Fold the fish while it is still fresh. If it dries, it will break."

${ }^{130}$ 5:11

$131 \quad 5: 12$
} 
Ebo: When the cock crows, the lazy man blames the night for being too short.

Asera: All we are saying is you need to be careful! Remember what the Akan elders say, edzidzi daa ye sen edzidzi preko. ${ }^{132}$ highlighted "What is bad luck for one man is good luck for another."

$\overline{132}$ Lit. "Eating every day is better than eating all at one time"

(C) Copyright 2020, Noyam Publishers | www.noyam.org 


\section{ACT 4: SCENE II}

Danyin: Do I have a choice? Why do I have to work if whatever I gain is unbeneficial? What does the worker gain from his toil? Is work fruitless?

Asera: Do not think all is unbeneficial. Sometimes, a bad thing can be good in a sense. That is why my Ga grandfather says, gboms fon hi fe shia folo. ${ }^{133}$

Ebo: It is not working to gain that is a problem. The real issue is gaining from work. The Akan says, Sika enyiber da owu afa. ${ }^{134}$

Abaeku: The Ewe people say, To medela menua $\varepsilon$ ba $0 .{ }^{135}$

Perba: Yes, it is said, "A new broom sweeps clean, but it is an old broom that knows the corners." There is nothing better for a person than to enjoy his/her work, because that is his/her lot.

Ayewa: Hmmm! As we said earlier, there is a time to everything and there is a season for everything under the sun. Each generation will reap what the former generation has sown. In this meaningless life of mine I have seen both of these: a rich man perishing in his riches, and a poor man living long in his little. ${ }^{136}$ My great grandfather said, "A gem is not polished without rubbing, nor a man perfected without trials."

Abaeku: That is why it is good and proper for a man to eat and drink and find satisfaction in his toilsome labour during the few days of existence that God gives. ${ }^{137}$ Again it is said, "A diamond with a flaw is worth more than a pebble without imperfections."

\footnotetext{
${ }^{133}$ Lit. "A bad fellow by your side is better than an empty house."

${ }^{134}$ Lit. "The one who coverts money is on the way to death."

${ }^{135}$ Lit. "The one who goes to draw water does not drink mud." Water becomes muddy after trying to draw it from a stream. Hence it is wise for the one who is thirsty to drink first before it turns muddy.

${ }^{136} 6: 3$

137 5:18
} 
Perba: It is said, "Do not be over-righteous, neither be over-wise why destroy yourself? Do not be over-wicked, and do not be a fool - why die before your time? ${ }^{138}$ It is said, "too much wisdom lets the animal escape from the trap."

Ayewa: Our elders say, "It is not the feathers on the fowl that makes it big." Likewise, it is said, "Too much leaves wrapped around kenkey does not improve its value." 139

Ebo: Did the Teacher say that many people find no end to their toils of life because they are driven by envy of what others have? The Akan elders also say, sika tse de akoa, ennhu do hwe a, oguan. ${ }^{140}$

Ntsifor: You cannot say that young man. I have seen the burden God has laid on the human race. So human beings are always searching relentlessly and grasping endlessly. But God has made everything beautiful in its time. It is said. "by crawling, a child learns to walk."

Perba: Only fools do not learn from their experience. It is only the toad that gets up on its knees and falls back on its knees again. The Swahili elders say, Mtoto umleavyo ndivyo akuavyo. ${ }^{141}$

Abaeku: The Akan says, se nye nkoks posa eburow a, hon enyi nnss wo. ${ }^{142}$ Let me sing you a song:

Ewia efir

Mfifir refir

Edwuma aber

Nduadzewa refir

Moks ekefir

${ }_{138} 7: 16$

139 The kenkey is a staple made of corn wrapped in leaves. Using many leaves to wrap a size of corn dough can give an impression that the food in the wrap is plenty.

${ }^{140}$ Lit. "money is like a servant. If you do not take care of it as you should, it runs away."

${ }^{141}$ Lit. "A child will grow the way you raise him/her."

${ }^{142}$ Lit. "If you remove corn seeds from the husk with fowls, they do not respect you." This is to say that you cannot restrict fowls when engaging in removing of seeds from the corb because that is their staple. They will never heed to advice that they should not consume some. 
Fir anee kesi boka

Aful nkwanta kodu Brafew

Obiradzi kesi sbrafew

M'atsew

M'afefew

M'afrow

M'ahwer mfifir

M'edzi

Mfifir ye nkyen mpo a

Ewiei no ye enyigye

[Translation]

The sun is high

Sweat is dripping

Work is on

Plants are growing

I will go on until

From East to the North

Aful Nkwanta to Brafew

September to October

I will plant

I will transplant

I will mix up

I will sweat

I will eat

If the sweat is salty

The end will be happiness 


\section{ACT 5-SCENE I}

Ebo: What are we waiting for? Isn't it time to start eating?

Ntsifor: Have we said the prayer?

Abaeku: What prevents you from saying the prayer if you are in a hurry, Ebo?

Asera: Hahaha, some air is blowing in his tummy.

Ebo: As tradition goes, it is Perba who prays because we are in her court. Casting insinuations about someone's hunger will bring a fight which I cannot settle.

Ayewa: Can there be silence for Perba to pray.

Perba: O Ataa Naa Nyənmo, ${ }^{143}$ before we open our mouth, you know everything. Bless what you have provided for us and send famine away from our sight. Since today is the king's day, may your favour come upon us.

\section{All: Amen.}

Danyin: Your prayer reminds me of our political system. I have seen that every king's successor is not pleased with what the predecessor did. ${ }^{144}$ Now who is responsible for such failure of leaders? Why do they not live up to expectation?

Ayewa: Fools can be placed in high positions while the wise occupy low ones. ${ }^{145}$ Remember that the Ewe people say, Fia eve mensa zikpi deka dzi o. ${ }^{146}$

\footnotetext{
${ }^{143}$ Lit. "Grandfather and Grandmother God." This is the traditional way the Ga people call God.

$1444: 5$

$14510: 6$

146 Lit. "Two kings do not occupy the same throne."
} 
Ebo: Certainly, "if a quantity of water does not suffice for a bath, it will at least be sufficient for drinking."

Asera: I have seen slaves on horseback, while princes walk on foot like slaves. ${ }^{147}$ Do not underestimate what slaves can do. The Akan says, onyina no ho nnye dzen naaso otutu hwe ndua a woye dzen do a, obubu hon posuoposuo. ${ }^{148}$

Abaeku: Hey you, remember that it is said, "woe to the land whose king was a servant and whose princes feast in the morning. Blessed is the land whose king is of noble birth, and whose princes eat at a proper time for strength and not for drunkenness." 149

Perba: A little advice for you. Rulers are unpredictable. Do not revile the king even in your thoughts, or curse the rich in your bedroom, because a bird in the sky may carry your words, and a bird on the wing may report what you said..$^{150}$

Ebo: If a ruler's anger rises against you, do not leave your post. Calmness can lay great errors to rest. ${ }^{151}$

Ntsifor: Please do not forget that "walls have ears."

Asera: My Ga grandmother says, mo ko ke ebsku estosn etsemei awe. ${ }^{152}$

Abaeku: The strange part is that fools never seek wisdom. If the axe is dull and its edge is not sharpened, more strength is needed. But skill may bring success. ${ }^{153}$

\footnotetext{
${ }^{147} 10: 7$

${ }^{148}$ Lit. "The silk-cotton tree is not a hard tree but when it falls upon trees with hard wood, it breaks them utterly into pieces."

149 10:16-17

$15010: 20$

$151 \quad 10: 4$

${ }^{152}$ Lit. "no one uses the left hand to point to the father's house." Traditionally, the left hand represents something weak one or dirty and thus when used connotes disdain for what one possesses.

153 10:10
} 
Ayewa: No wonder in Swahili it is said: Raslimali ya mnyonge $n i$ umoja. ${ }^{154}$

${ }^{154}$ Lit. "The significant resource of the weak is unity."

(C) Copyright 2020, Noyam Publishers | www.noyam.org 


\section{ACT 5 : SCENE II}

Danyin: Why is it that kings wield so much power?

Abaeku: Some kings behave as if they are the saviour of the world. They want to be in control of everything and end up loosing control of all. It is said, "Looking at a king's mouth one would never think he sucked his mother's breast." However, obey the king's command, because you took an oath before the Lord to be respectful. ${ }^{155}$

Ntsifor: It is said, "Do not be in a hurry to leave the king's presence. Do not stand for a bad cause, for he will do whatever he pleases."156

Perba: Yet still, those who sing their praises are the same who plan for their downfall. The Hausa elders say, Albas aba tayi halin ruwaba. ${ }^{157}$

Ebo: Do not mind those arrogant kings! "If you look at an old woman's teeth, you may think she has not chewed bones before." Since a king's word is supreme, who can say to him, what are you doing? ${ }^{158}$

Asera: Know this: For the word of the king is powerful, and whoever obeys a command will meet no harm, and the wise must know the time and way. In Akan it is said, Abofra ye soma kor a, odzi abodweedze. ${ }^{159}$ In fact, a child who knows how to wash the hands can eat with adults."

Abaeku: Again, "it is only when you are brave that you kill an elephant."

Ayewa: "A big throne does not make a good king."

Ebo: Better to hear the quiet words of a wise person than shouts of a

${ }^{155} 8: 2$

$1568: 3$

${ }^{157}$ Lit. "One cannot explain how the onion is able to wet one's eyes."

158 8:4

159 Lit. "A child who is always ready to be sent, eats what is desirable." 
foolish king. Let me sing a song:

How can I be silent if all is quiet? How can I be quiet if all is silent?

My hands on my lips speaks a lot My closed mouth saying so much

When I speak, I am too loud When I am quiet, I am too dull Mumbling has too much tone Miming a little pitch to tune

Say you! say me!

That is what the world is all about Since I cannot have my own way My Maker will speak for me. 


\section{ACT 6 - SCENE I}

Ntsifor: I smell something! Where did some of you pass before coming to table?

\section{Ayewa: Ask them?}

Asera: Let us smell each person's breath to see if ...

Ebo: Nobody is drunk here. We all decided not to drink before the meal the other time.

Perba: So this table has become a testing place for breath measurement? May the one who will do the smelling not be caught blowing hot air into people's mouths.

\section{Abaeku: Let us stop all that and allow Ntsifor to pray.}

Ntsifor: Almighty One! You have declared that all who do not work must not eat. You gave us strength to make a big farm and now we are enjoying the work of our hands. Let your blessings come upon us.

\section{All: Amen}

Danyin: Tell me something! Some work hard but are poor. Others are lazy but are wealthy. Why do some people seem to have advantage over others? Or you suppose everyone has the same lot; young or old, rich or poor, hard work or lazy bones?

Abaeku: Although a wicked man commits a hundred crimes and still lives a long time, I hear that it will go better with God-fearing men, who are reverent before God. The Akan say, wodze nam na wo dze tsi nam. ${ }^{160}$

\footnotetext{
${ }^{160}$ Lit. "you have to use fish to capture a fish". This means that grouping like things together is the right thing to do.
} 
Ebo: Hmm! There is something else meaningless that occurs on earth: righteous men who get what the wicked deserve, and wicked men who get what the righteous deserve. In fact, "all lizards crawl on their bellies as if they have a problem. So, it is very difficult to detect the lizard with an upset stomach." Why the wicked lives long is meaningless too, I say, is meaningless. Well, "Deep doubts, deep wisdom; small doubts, little wisdom."

Abaeku: So, I commend the enjoyment of life, because nothing is better for a man under the sun than to eat and drink and be glad. Do not try poverty. In fact, a Bena proverb goes: Uwuhangala wupyo simwoneka pamiho, nde ulefihe upye. ${ }^{161}$

Abaeku: It may seem so but there are three grave anomalies under the sun. First, wealth hoarded when people need them and it eventually harms the owners. Second, wealth lost through some misfortune so that when they have children, there is nothing left for them to inherit. And third, both the child that is born and the dead come or go emptyhanded. ${ }^{162}$

Ebo: My Ga great grandfather says, mo ko епиии tsofa ehaaa helatse. ${ }^{163}$

Perba: I have also seen something that is good. First, it is appropriate for a person to eat and drink and find satisfaction in their toil under the sun. Second, when God gives someone some wealth or possession, he gives them the ability to enjoy their lot. They seldom become worried because God keeps them occupied. ${ }^{164}$

Ayewa: The Akan says, se wonya nnwa na wose w'afa asaasede a, nya swo na hwe. ${ }^{165}$

\footnotetext{
${ }^{161}$ Lit. "Poverty is like heat. You cannot see it. You can know it if you go through it."

${ }^{162}$ 5:14-17

${ }^{163}$ Lit. "No one drinks medicine on behalf of a sick person."

${ }^{164}$ 5:18-20

${ }^{165}$ Lit. "if you pick a snail and you claim you have chanced upon a gift, then pick a snake."
} 


\section{ACT 6: SCENE II}

Danyin: On the other hand, I have also seen another evil under the sun. God gives some people wealth, possessions, and honour so that they lack nothing they desire. But God does not grant them the ability to enjoy them, and strangers enjoy them instead. ${ }^{166}$

Ebo: A man may have a hundred children and live many years; yet no matter how long he lives, if he cannot enjoy his prosperity and does not receive a proper burial, I say that a stillborn child is better off than he. Certainly, even if he lives a thousand years twice over but fails to enjoy his prosperity, he is nothing. ${ }^{167}$

Asera: That is why the value of life is not in what you have but in how you value what you have. Remember, my Ewe grandmother says, Adaba kple ge mekea di o. ${ }^{168}$

Abaeku: Everyone's toil is for their mouth, yet their appetite is never satisfied. People always crave for more no matter how much they get. ${ }^{169}$

Perba: That's not all, young man. The evil I have seen under the sun is that the hearts of people are full of evil and there is madness in their hearts while they live. ${ }^{170}$

Asera: The Akan elders say, opanyin na obi nnye bi da, na abofra dze obiara aye bi da. ${ }^{171}$

Ntsifor: In life, there are some who are smart. When they tell you to look up, better look down.

\footnotetext{
$1666: 1-2$

${ }^{167} 6: 3$

${ }^{168}$ Lit. "The beard does not challenge the eyelashes."

$1696: 7$

$1709: 3$

${ }^{171}$ Lit. "Not everyone has been an old person before, but everyone has been a child before."
} 
Danyin: Is there any reassurance in the hope of a life to come, where good and evil will find their respective appropriate rewards? Who knows? So far as we can tell, man dies like the beast. ${ }^{172}$

Ntsifor: The Teacher says, "I find more bitter than death the woman who is a snare, whose heart is a trap, and whose hands are chains. ${ }^{173}$ Don't get me wrong, I mean a woman who is dangerous. The Akan says, Inya ascm pa a, mma nnka nnkyere wo yer. ${ }^{174}$

Ayewa: Hmmm, notwithstanding listen to this! Anyone who is among the living has hope. A living dog is better than a dead lion. ${ }^{175}$

Ebo: The Ga people say, Ahaa mo yoo ni aha le saa hu afata he. ${ }^{176}$

Perba: Indeed, there is no one on earth who is righteous; no one who does what is right and never sins. ${ }^{177}$

Asera: The Akan forefathers say, basia tse de kuntu; edze kata wo do a na woho keka wo. Eyi fi woho a, na awow dze wo. ${ }^{178}$

Asera: Yet because the wicked do not fear God, it will not go well with them, and their days will not lengthen like a shadow. ${ }^{179}$

Abaeku: It is said, "the poor person and the rich person do not play together." It is time for me to sing my song:

Who am I?

Sitting somewhere

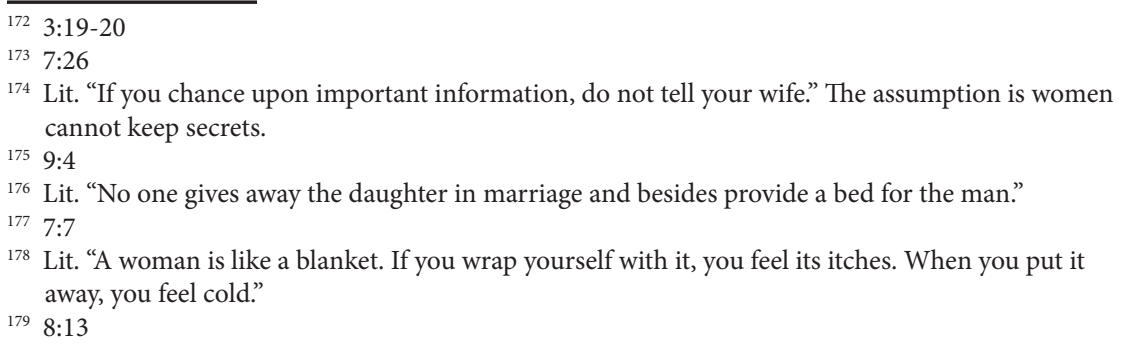


somehow some are

A miracle in flesh

hoping I can think of Who I am

Who am I?

Walking to and fro

Gazing at the wind

Some how in the sun

Hoping I can sing about Who I am

Who am I?

Sleeping on my bed

O my little love

Some how to the great One

Am a heir to Whom 


\section{ACT 7-SCENE I}

Abaeku: Today we have met early.

Asera: This shows that our young sister, Danyin, is fast.

Ebo: I wish she knows how to cook my favourite.

Ayewa: It is not because of your favourite that is why we are here. Selfish man.

Perba: Why the argument?

Ntsifor: Let us eat before we continue the argument as to who is selfish. Maybe by then we will have more strength to argue. It is not wise to fight when food is set before you. Danyin, pray and let us proceed.

Danyin: Bless us O Lord!
All: Amen.

Danyin: I think wisdom is better than strength. Using one's mind to be creative and rich is better. Am I not right?

Ntsifor: The Akan says, Akoks saw den ara a, orennye akroma $f \varepsilon w .{ }^{180}$ Whoever strives for wisdom will never have enough. But wisdom is better than folly just as light is better than darkness. ${ }^{181}$

Ebo: As your wisdom increases, so do those who come to tap from it. Woe to you when no one approaches you for wisdom.

Perba: I have not seen a wise person who is afraid to lose his or her wisdom. The more wisdom is shared, the more one grows wiser. It is ${ }^{180}$ Lit. "No matter how the hen dances, it will never please the hawk." $1812: 13$ 
said, 'do not be over-righteous, and do not be over-wise.' 182

Abaeku: Yours is a small matter. I know a rich man. He did not want people to know the extent of his wealth and so kept the wealth in the name of a family member at the treasury. All he does is to look out if that family member will take what belongs to him.

Asera: Holala, sleep is sweet only for those who have eyes to sleep.

Ayewa: Our Akan grandfather wrote on his lorry, Sika mmpe rough. ${ }^{183}$

Asera: Who said that the big head has more wisdom? Then what will we say about the crab?

Danyin: Nevertheless, the Ewe people say, Akufia dadi equa afi $k u k u .{ }^{184}$

Abaeku: Many people think that progress in education and technology is the key to life. Despite all the discoveries, there is still more to explore. Yet, there is a time to search and a time to give up.

Perba: Listen to this! Here is another bit of wisdom that has impressed me as I have watched the way our world works. There was a small town with only a few people and a great king came with his army and besieged it. A poor wise man knew how to save the town so he rescued it. But afterwards no one thought to thank him. ${ }^{185}$ The Akan say, Komfo bon a w'atsena yarfo ho ma komfo pa absto no no, wonnyi no eтио. ${ }^{186}$

Ntsifor: Who can straighten what is already crooked. Who can count

\footnotetext{
$1826: 16$

${ }^{183}$ Lit. "money cannot be toyed with."

${ }^{184}$ Lit. "The lazy cat eats dead mice."

185 9:13-15

${ }^{186}$ Lit. "The bad fetish priest who has been taking care of the sick should not be forgotten when a good fetish priest arrives."
} 
what is lacking. ${ }^{187}$ It is the fool who says, "They mean my neighbor, not me." Wisdom is better than weapons of war. ${ }^{188}$

Asera: Even Kweku Ananse could not collect the entire wisdom in the world. Excessive wisdom is to be avoided as much as excessive wickedness and folly.

Ebo: The Setswana people say: Ba kele di tsa mathe. ${ }^{189}$ Wisdom has its limitations. It is not a completely reliable shield in times of adversity.

Ayewa: Our elders say, "Wisdom is like a baobab tree. No one person can embrace it." In moments of crisis, the wise build bridges and the fool builds dams.

Perba: A wise person chooses the right road; a fool takes the wrong one. You can identify fools just by the way they walk down the street, especially when they see nice, nice things. You get what I am saying?

Asera: The race is not for the swift or the battle for the strong, nor does food come to the wise or wealth to the brilliant or favour to the learned. But time and chance happen to them all.

Abaeku: It takes the prudent to distinguish white wine and plain water. The Akan say, ssono adwen na ssono nyansa. ${ }^{190}$

Ntsifor: The elders say, "Advice is a stranger. If it is welcomed, it stays for the night. If not, it leaves the same day."

Ayewa: It is the Akan elders who say, Abofra bo nwa, ommmo akyekyedec. ${ }^{191}$

\footnotetext{
$187 \quad 1: 15$

188 9:18

189 Lit. "You cannot wash your face and pretend to be weeping."

${ }^{190}$ Lit. "There is difference between an advice and wisdom."

191 Lit. "A child may swallow a snail, but not a tortoise."
} 


\section{ACT 7: SCENE II}

Danyin: Can anyone help me to understand the significance of wisdom?

Ntsifor: The value of wisdom is that it helps a person to succeed. It is said, "Good beads do not make loud noise."

Perba: Oh I see! Fools base their thoughts on foolish assumptions, so their conclusions will be wicked madness. The Sukuma people say: Kumugamuga nsatu, ng'hungu. ${ }^{192}$

Ebo: Listen! A poor man's wisdom is despised, and his words no longer needed. ${ }^{193}$ The Akan says, Ohia ma adwene. ${ }^{194}$ Wisdom does not guarantee a good job or honorable position.

Asera: Wisdom is like an inheritance. It is a good thing and benefits those who have it.

Asera: Wisdom is a shelter, as money is a shelter, but the advantage of knowledge is this: wisdom preserves those who have it.

Ntsifor: Wisdom can make one wise person more powerful than ten rulers in a city.

Danyin: I think I am getting an impression. What you all seem to say is that wisdom has its strengths, so we must live not by sight. The Builsa elders say, Niwobo kpiale ale ka jam chim wa naab. ${ }^{195}$ The value of something does not lie with the one who does not know anything about it.

Ayewa: There are so many unexplained enigmas, unresolved ${ }^{192}$ Lit. "If you hide a sick person, he or she will betray you with groans."

193 9:16

${ }^{194}$ Lit. "Necessity is the mother of invention." It may be that, at a point of need, a clue can be found.

${ }^{195}$ Lit. "The poor man's fowl becomes his cow." This implies that the little that a poor man has can be a prized thing to him. 
anomalies, and uncorrected injustices in this world, and in all these human beings cannot comprehend them.

Perba: It is said, "the one who causes others misfortunes, also teaches them wisdom."

Ebo: There is no human being who does not make a mistake. ${ }^{196}$ The Akan say, mbowa nyina tu enguan, nantwi nkotsee tu mbirika a, wo se w'absdam. ${ }^{197}$

Asera: Remember, to err is human. Moreover, the words from a wise man's mouth are gracious, but a fool is consumed by what comes out from his/her own lips. The elders say, "It is better to be silent like a fool than to talk like one."

Abaeku: The words of the wise are like cattle prods - painful but helpful. Our wise sayings are like a nail-studded stick with which a shepherd drives a sheep. Of anything beyond these, my friends, beware. It is said, "too much wisdom caused the crab to lose its head."

Ntsifor: Alright, let me tell you this. Life without God has no meaning. Life without wisdom is vanity. That is why life is meaningless vanity. Confidence in human-based achievements, human technology and wisdom in human beings lead to dissatisfaction and emptiness. The only answer to the meaning of life is to fear God and enjoy one's lot.

Asera: In Swahili, it is said: Asiyesikia la nkuu huvunjika guu. ${ }^{198}$ So fear God. That's all. Hear my song:

Don't you understand

That life is in the hands of the Creator

God holds your life

\footnotetext{
196 7:20

${ }^{197}$ Lit. "All animals run. When the cow runs, people say it is mad."

198 Lit. "A person who does not listen to the advice of the elders gets the leg broken."
} 
God directs your life

God takes the step ahead of you

Don't you understand

When you follow God your Creator

Everything is not in the hands of God

You will give an account of your life

Don't you understand

That wisdom is in the depths of God

God made wisdom

God gives wisdom

God grants wisdom to all who seek it

Don't you understand

When you have no wisdom

All your life is foolishness

Everything is not in the hands of God

You will give account of your wisdom

Don't you understand

That God created you and I

You help me

I help you

The world becomes a better place

Don't you understand

When you destroy your neighbour

Thinking only about yourself

Everything is not in the hands of God

You will give account of your relationship

I do understand

That I am here for you

And you for me

My feeble actions

Can make things right 
I do understand

My good will bring joy

My bad will bring shame

Everything is not in the hands of God

May my actions be good 


\section{ACT 8 - SCENE I}

Danyin: Medaase. ${ }^{199}$ I may be nobody but let me ask this! Why is it that the actions of both the righteous and the fool are in the hands of God? Do all share the same destiny, the righteous and the wicked, the good and the bad, the clean and unclean, those who offer sacrifices and those who do not? What option can I take?

Abaeku: In fact, the Chewa people have a proverb that may be relevant here: Mlendo amayenda ndi lumo lakuthwa. ${ }^{200}$

Ntsifor: Well, well well! Some people claim to be wise but they are fools. The Teacher says, "extortion turns a wise person into a fool and a bribe corrupts the heart." ${ }^{\text {201 }}$ Many people think bribery and corruption is a simple matter

Ayewa: It is the vulture who always sing during rainy days that tomorrow I will build my house.

Ebo: The words from the mouth of the wise are gracious, but fools are consumed by their own lips. ${ }^{202}$

Danyin: From what you are saying, I desire and am determined to be wise but this is not possible because it is far beyond my reach. Why not go for a drink and cool my heart?

Abaeku: Enjoy life with your wife. Enjoy the fruit of your hands, because it is good and proper for a man to eat and drink, and find satisfaction in his toilsome labor under the sun during the few days of life God has given him - if this is our lot

\footnotetext{
199 A remark of appreciation in Akan that means "thank you"

${ }^{200}$ Lit. "A traveler moves about with a sharp razor." That is to say, the alien outsider may at times be in a better position to provide a more discerning, balanced, impartial, or novel viewpoint on a particular issue than a cultural insider simply because he/she is looking at things either analytically or experientially with a completely different set of cognitive and emotive spectacles.

$2017: 7$

$202 \quad 10: 12$
} 
Perba: Go, young man. Eat your food with gladness, and drink your wine with a joyful heart, for God has already approved what you do. ${ }^{203}$

Ntsifor: It is the fool who doesn't enjoy life. A party makes you feel good, wine makes you feel happy, and money buys anything. ${ }^{204}$

Ayewa: Let your garments be always pure and always anoint your head with ointment. ${ }^{205}$ Enjoy in the right way.

Asera: It is God who gives someone wealth and possessions, and the ability to enjoy them. This is a gift of God. The Akan say, sika te se nkrante a cye nnam. Wode gyina ascm mmirikisi anim a, cnnkye na aka no ato fam. ${ }^{206}$

Ebo: Wisdom brightens a man's face and changes his hard appearance. ${ }^{207}$

Perba: The Oromo elders say: Hoggaa gabbattuun barraaqthu. ${ }^{208}$

Abaeku: It is the wise who enjoys life. Enjoy life with the wife, whom you love, all the days of this meaningful life that God has given you under the sun. For this is your lot in life. ${ }^{209}$

Ebo: It is said "if you have not gone to someone's farm, you assume yours is the best."

Asera: It is also said, "the one who only eats from the mother's pot assumes that only his/her mother cooks the most delicious meal."

\footnotetext{
$2039: 7$

$204 \quad 10: 19$

205 9:8

${ }^{206}$ Lit. "Money is like a sharp cutlass. If it confronts a thick bush, it soon levels it to the ground." It proves the ability of money to solve difficult problems.

207 8:1

${ }^{208}$ Lit. "When the fat cows jump with joy, the thin ones raise their tails.

209 9:9
} 
Ntsifor: My grandmother will say in Akan, Se suro awar gyaa a, onnya awar papa. ${ }^{210}$ That does not mean one should hop from marriage to marriage. It is a fool who thinks a new marriage will give a better result.

Abaeku: The Igbo people say, Ebe enwe no ka olete cha ihe nile na erne ka mgbo ji tuo ya na si. ${ }^{211}$ A person must avoid opening the eyes too wide into everything. We should be content with little, even when it comes to choosing women.

Ntsifor: It is the fool who is not cautious when taking decisions. The Akan say, kur a oboku kraman na sts n'apampam mu. ${ }^{212}$

Ebo: In fact, a broad perspective of life is the best. One must not be close-minded because there are new ideas, alternatives and diverse views about every situation. The Akan elders say, Wo sikayi ye wo yaw na wo ko ko a, wonnyi dom. ${ }^{213}$ So live wisely.

Asera: Whatever your hand finds to do, do it with all your might and in joy, for in the realm of the dead where we are going, there is neither working nor planning nor knowledge nor wisdom. ${ }^{214}$

Ntsifor: Whoever digs a pit will fall into it. Whoever breaks through a wall may be bitten by a snake. Whoever quarries stones may be injured by them. Whoever splits $\operatorname{logs}$ may be endangered by them. ${ }^{215}$

Ebo: The Teacher says, "You who are young, be happy while you

${ }^{210}$ Lit. "If you hate divorce, you will not get a good wife."

${ }^{211}$ Lit. "It is while the monkey was insisting on seeing everything in a procession that a bullet hit his head."

${ }^{212}$ Lit. "The wound that will kill the dog appears on the skull." The dog cannot lick such a wound for it to heal well and cannot do away with flies. Moreover, the smell from the wound on top of the head of the dog interferes with other smells so the dog cannot discern a bad thing from a good thing with smell.

${ }^{213}$ Lit. "If spending your money gives you pain and you go to war, you do not get a crowd." This means if you are a miser, people will not follow you to celebrate victory.

214 9:10

215 10:8-9 
are young and let your heart give you joy in the days of your youth. Follow the desires of your heart, and whatever your eyes see, but know that for all these things, God will bring you into judgment."216

Abaeku: Do not forget that he also says: "banish anxiety from your heart and cast off the troubles of your body, for youth and vigor are meaningless." 217

Ayewa: Do not pay attention to every word people say, or you may hear your servant cursing you. You will think that because you have been cursing people many times yourself, another person is cursing you.

Rap, rap, par, far, mar.

Hop, hip, poh, pam, tap.

Ring, ding, sing my song

Dance a body shake

Joy, joy, in the sky

Fun, fun, is my share

Party time is come to town

Blessing all the while I know. 


\section{ACT 8 - SCENE II}

Danyin: Cheers! Cheers!! Cheers!!!

Ntsifor: So you are happy? Hmm. Little children, little brains. How can a child whose brains are underdeveloped know so much? But it is possible in this life.

Perba: If you do not have money, you say money is not good. When children do things, we say such children are witches and wizards because they display extraordinary skill.

Ayewa: If clouds are full of water, they pour rain on the earth. Whether a tree falls to the south or to the north, the place where it falls, there it will lie. ${ }^{218}$

Ebo: One cannot be what he is not. We can only enjoy what we have and not what we do not have. Sometimes people want to enjoy what they do not have. Does that make sense? I believe it is better to listen to the wise who says, "Go, eat your food with gladness, and drink your wine with a joyful heart, for God has already approved what you do." 219

Abaeku: Whoever watches the wind will not plant; whoever looks at the clouds will not reap. ${ }^{220}$ It is not always that the clouds gather and become very visible that it rains. Even a little gathering of the clouds can give much rain. So with the little you have, enjoy - be happy.

Perba: It is said, sow your seed in the morning, and at evening let your hands not be idle, for you do not know which will succeed, whether this or that, or whether both will do equally well. ${ }^{221}$

Ntsifor: As for me I know that happiness is an illusion. The Akan 
say, wo besi wo do, nna wohye wo ma. ${ }^{222}$ However, If God calls us to be happy, then why not?

Ayewa: Nevertheless, I commend the enjoyment of life, because there is nothing better for a person under the sun than to eat and drink and be glad. Then joy will accompany them in their toil all the days of the life God has given to them under the sun. ${ }^{223}$

Asera: No matter the number of years a person may live, let him or her enjoy them all. ${ }^{224}$ If it is true that only the fool postpones enjoyment, then I will go for it.

Ntsifor: Do not say that loud! The Igbo elders say, Anaghi atupe ngwugwu aga emepe emepe. ${ }^{225}$ Patience is a good virtue and can make a person enjoy well. You cannot drink the soup while the fufu is being pounded.

Abaeku: A person can do nothing better than to eat and drink and find satisfaction in their own toil. This too, I see, is from the hand of God, for without him, who can eat and find enjoyment? ${ }^{226}$

Asera: Hmm "All that God has done. No one can comprehend what goes on under the sun... a human being cannot discover its meaning. Even if a wise man claims he knows, he cannot really comprehend it. Of the making of research, there is no end, and much study is a weariness of the flesh. ${ }^{227}$

Abaeku: The Teacher has searched for all the right answers and what she wrote is upright and just. ${ }^{228}$

\footnotetext{
${ }^{222}$ Lit. "If you will be given a second chance, the first will be full." That is to say, the first time you ask for water, you are given half full. If there is enough, you will be given a full glass. So why ask for more?

$2238: 15$

${ }^{224} 11: 8$

${ }^{225}$ Lit. "One must not pinch the side of a parcel that he or she is expected to open."

226 2:24-25

$227 \quad 12: 11$

$228 \quad 12: 10$
}

(C) Copyright 2020, Noyam Publishers | www.noyam.org 
Ebo: Only one thing is meaningful. Life has lost its key to itself. But there is the locksmith who made the lock. There is the creator who holds the key to all that is unknown. Since you cannot get the key, you must trust the locksmith to open the doors of life to you.

Ayewa: Remember your creator in the days of your youth, before the days of trouble come and the years approach when you will say, 'I find no pleasure in them'. ${ }^{229}$

Abaeku: The elders say that if you make a farm and God does not see it, it would not yield anything.

Ntsifor: A time will come when someone will hold your hands to see the sun. A time will come when the doors of the city will be closed. A time will come when you will be afraid of heights. A time will come when you will drag your feet as you walk. A time will come when desire no longer is stirred. There you will understand that you have wasted the best part of your years.

Perba: Remember your creator before the silver cord is severed, and the golden bowl is broken; before the pitcher is shattered at the spring, and the wheel broken at the well. ${ }^{230}$

Ayewa: Farafara farafara. ${ }^{231}$ Now all has been heard: here is the conclusion to the matter. Fear God and keep his commandments for this is the duty of mankind. For God will bring every deed into judgment, including the hidden thing, whether it is good or evil. ${ }^{232}$

Asera: Our Ga forefather says, Aekoo hi fe sce fee..$^{233}$

Ebo: In fact, I agree with the Builsa that wari kan kperi saalo. ${ }^{234}$

\footnotetext{
229 12:1

230 $12: 6$

${ }^{231}$ A greeting among the Gurunes (Fafra) which means well done.

232 12:13-14

${ }^{233}$ Lit. "To be told 'well done' is better than 'How did it fare?"”

${ }^{234}$ Lit. "Proverbs cannot perplex a man."
} 
Abaeku: The Akan says, ascm $s \varepsilon b \varepsilon^{235}$

Danyin: I have heard all that you have said. I have also examined all aspects life - wisdom, folly, leadership, pleasure, toil, and wealth. You name it? You have helped me to find wisdom to realise I have more ahead of me. Yes, nothing is better than wisdom. The path of pleasure is vanity but it is better to enjoy life with wisdom. All is toilsome but it has its rewards. Now this is the conclusion of the matter - fearing God and keeping his commandments. That's the beginning of it all and that's the end of it all. You have all spoken to me like wise people.

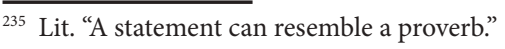




\section{PART THREE \\ Understanding The Wisdom \\ Of Ecclesiastes}

\section{Background to the Book of Ecclesiastes}

The book of Ecclesiastes, admittedly, is one of the most difficult books in the Bible. Its Hebrew title is Qoheleth. Many have looked at the book with some suspicion and wondered how it fits within Christianity. Most commentators have observed from the book some non-traditional theology and defiant viewpoints. George Barton sees the author as a sceptic but one who has not totally abandoned faith in God. ${ }^{236}$ RK Johnston calls the author a "depressed workaholic."237 RBY Scott sees the message of the book as "philosophical nihilism." 238 James Reitman says the book has a cynical tone, which tends to pull the reader towards despair. ${ }^{239}$ William P. Brown says he is a "radical empiricist of antiquity." ${ }^{240}$ Many commentators liken him to a pessimist who is without hope. ${ }^{241}$ To approach the book of Ecclesiastes with rational and spiritual lenses may lead to the loss of its most essential essence and impact - wisdom and poetry. It takes a child-like faith to get into the world of the author.

Ecclesiastes is one of the three books categorized under Wisdom Literature in the Old Testament, a genre that reflects ideas,

${ }^{236}$ George A. Barton, A Critical and Exegetical Commentary on the Book of Ecclesiastes, ICC

(Edinburgh: T\&T Clark, 1959), 49.

${ }^{237}$ R.K. Johnston, “Confessions of a Workaholic: A Reappraisal of Qoheleth,”CBQ 38 (1976):15.

${ }^{238}$ R.B.Y. Scott, Proverbs \& Ecclesiastes: Introduction, Translation and Notes, AB (Garden City: Doubleday \& Company, Inc., 1982), 202.

${ }^{239}$ James S. Reitman, “The Structure and Unity of Ecclesiastes," BSac (1997): 298.

${ }^{240}$ William P. Brown, “'Whatever your Hands finds to Do': Qoheleth's Work Ethic," Interpretation (2001): 271.

${ }^{241}$ J. Strafford Wright, "Ecclesiastes,"in The Expositor's Bible Commentary - Volume 5, ed. Frank E. Gaebelein (Grand Rapids: Zondervan, 1991), 1144; Craig G. Bartholomew, Ecclesiastes (Grand Rapids: Baker Academic, 2009), 68. 


\section{THIS COPY IS NOT FOR SALE}

assumptions, philosophies and goals of wisdom. The others are Job and Proverbs. James Crenshaw opines that "wisdom is the ability to cope; the act of steering; it is practical knowledge of the laws of life and of the word, based on experience; wisdom constitute 'parents legacy to their children'; it is the quest for self-understanding and for mastery of the world." 242 That is to say, wisdom is a way of looking at the world in very deliberate terms. It seeks to teach practical moral principles for behaviour or dares to raise its views about the many problems associated with human existence. Ideally, the book of Ecclesiastes focuses on certain aspects of such self-understanding of life and meaning of what happens around humanity in this world. It seeks to deal with some existential issues in light of the seeming meaninglessness of what happens in the life of people. It challenges the one-sided perceptions of orthodox theology and wisdom and offers opportunities to look at the other side of life. Even a casual reader will notice how blunt and real the sage has been.

The Old Testament is made of up of three distinct divisions: Law, Prophets, and Writings. Within the Writings are the category of Wisdom Literature, although what is distinctively seen as wisdom material can be found in almost all the books of the Old Testament. The book of Ecclesiastes belongs to the category of Wisdom Literature, and is placed between Proverbs and Songs of Solomon, perhaps to put together the traditions of Solomon. In the Jewish calendar, Ecclesiastes is read as a liturgical book on Sukkot, one of the five main festivals. Thus, it plays a key function in spirituality, and it is supposed to be read in the church for instruction and pedagogue.

The book of Ecclesiastes affirms that wisdom is a gift, yet not simply a perfect gift. It can also be acquired, even in its raw state, but there is more to it than can be discerned. Certainly, experience can be a way of acquiring wisdom. Yet, no matter how one comes by wisdom, it requires building upon its foundations with divine enablement and polishing it within the limits of human abilities. It is taught and learnt, a process where one must even disprove to prove. According to William P. Brown, biblical wisdom

${ }^{242}$ James L. Crenshaw, Old Testament Wisdom - An Introduction (Atlanta: John Knox Press, 1981), 16. 


\section{THIS COPY IS NOT FOR SALE}

embraces knowledge yet admits to uncertainty and severe limits. Wisdom is both eminently practical and rigorously intellectual. It draws from the natural order yet is also open to the unexpected, including the shock of divine revelation. Wisdom is a product of the community with its venerable traditions forged across generations, yet it also champions personal experience. Wisdom's appeal is universal, yet its advice can be highly contextual; a judicious course of action in one context can be sheer folly in another. ${ }^{243}$

What Brown seeks to assert is that biblical wisdom comes with its limitations whether through divine revelation or human knowledge. It may originate in the common life of a people to defy what revealed religion says, but it cuts across all people - the ordinary people as well as the elite; the young as well as the old; the poor as well as the rich.

Wisdom reflects on what is around us using pre-critical, critical, and un-critical methods, and would even explore spirituality from a naive point of view. Although wisdom is a reflective exercise, it acknowledges God at every step of the way. It does not provide a one-sided view of life; every position has its other side. An individual's relationship with God or other people can lead to fulfilment but can also lead to disappointment. Ideally, biblical spirituality acknowledges both the affirming voices and counter voices. In fact, the lament psalms clearly show how the faithful can suffer humiliation, disappointment and shame. Wisdom thrives in spirituality, and Walter Brueggemann calls attention to spirituality that acknowledges counter voices of disorientation that destabilizes equilibrium and coherence as acts of faith. ${ }^{244}$ Such spirituality is time-tested but can accept what is new. This means it is not only what people have come to know through time that matters, but also what can be known.

Wisdom makes a person wise but can easily make one a fool.

${ }^{243}$ William P. Brown, Wisdom's Wonder: Character, Creation, and Crisis in the Bible's Wisdom Literature (Grand Rapids: Eerdmans, 2014), 24.

${ }^{244}$ See Walter Brueggemann, The Message of the Psalms, AOTS (Minneapolis: Augsburg, 1984); See also Old Testament Theology: Testimony, Dispute, Advocacy (Minneapolis: Fortress Press, 1997), 54, 393. 


\section{THIS COPY IS NOT FOR SALE}

The Akan says, se w'enyi tsew pii a, ema aponkye akye (lit. "if you become too wise, you tend to greet the goat good morning"). The goat can deceive people and outwit many by its actions. To run after a goat, one must be cautious as it may influence the person to do the unthinkable. Hence, staying within the boundaries of thought and appreciating views in context are key in terms of wisdom.

Interestingly, the author of Ecclesiastes succeeds in reflecting and presenting various issues that are widely known and also pays attention to things many overlook. His style is spectacular. He explores related themes with valid conclusions yet in a haphazard and unconventional manner. Unfortunately, many have become disappointed at the style of the author and how he manages to disprove the traditional view about life. How can one who calls himself a king in the line of David, purporting to have authority over many things turn around to say all is vanity? At least, he can be seen as someone who has all in life, seen all in life, and knows all in life. Some expect him to be straightforward but he is not. R. N. Whybray proposes that "If it could be shown that these have been arranged in some kind of logical order by Qoheleth himself, this would greatly assist the understanding of his thought." 245 Yet to be coherent and logical would defeat what he sets out to do; affirming the meaninglessness of life. Choon-Leong Seow cogently observes that 'Qoheleth's purpose is not to present a systematic theological treatise. His reflections concern the practical realities of life and how one may cope in a world that is utterly beyond human control."246 Hence, wisdom cannot always be straightforward as people expect, and the author gives us a perfect example of that. Anyone who tries to look out for a straightforward answer to life and in the book of Ecclesiastes will be disappointed. It can be said that the lack of straightforwardness in the book has led many to say Qoheleth contradicts himself in many ways. Unfortunately, that is not so. I agree with Michael Fox, that Qoheleth is not contradicting himself

\footnotetext{
${ }^{245}$ R. N. Whybray, Ecclesiastes, NCBC (Grand Rapids Eerdmans, 1989), 19.

${ }^{246}$ Choon-Leong Seow, "Theology when Everything is out of Control," Interpretation (2001): 246.
} 
highlighting the contradictions in the world. ${ }^{247}$

In the book of Ecclesiastes, the author uses multivalent language, literary devises, and rhetorical strategies to draw home his views. The speeches are poetic, employing the techniques of irony, ambiguity and double-entendre to argue on contradictions and indeterminacy of meaning. ${ }^{248}$ Hebrew poetry, although in Scripture, is meant to be experienced and felt with all its tonal effects. A characteristic of biblical poetry is the way it comes with expressive qualities of words, conveying heightened forms of perception, experience, and emotional effects on the hearers. To feel such quality of words, one needs to read poetically, smoothly and solidly. Where there must be pausing over vivid imagery to make what is portrayed become real, the poet knows that you will pause to imagine that. Where the words invite you to giggle, smile or laugh, the poet knows you will do so. Hence, reading poetry is a give-and-take act and it allows readers to participate in the drama.

Biblical wisdom frequently uses poetry not only to teach its listeners but also to enable them to feel the delight of the language and thought. Thus, it is not out of place to see Ecclesiastes as one of the books of the Old Testament that uses poetry to the delight of its readers. Hebrew poetry illuminates the historical atmosphere of the people of God in worship, as well as their socio-cultural and religious lifestyles. It makes worship and common life relevant among people of faith. Unlike the Jews, the church in Africa is far from poetic life. The contributions of literary perspectives are yet to take firm roots in Christian spirituality and worship services. Within the Christian circles, it is difficult to appreciate dramatic and poetic beauty of the biblical text alongside spiritual lessons.

\footnotetext{
${ }^{247}$ Michael V. Fox, Qoheleth and His Contradictions (Decatur, GA: Almond Press, 1989).

${ }^{248}$ Eunny P. Lee, The Vitality of Enjoyment in Qohelets' Theological Rhetoric, BZAW 353 (Berlin: de Gruyter, 2005), 25.
} 


\section{THIS COPY IS NOT FOR SALE}

\section{Author}

From the book of Ecclesiastes, the author identifies himself as Qoheleth $(1: 1,2,12 ; 7: 27 ; 12: 8,9,10) .{ }^{249}$ However, only once does the "name" come with the definite article - "the Qoheleth" (12:8). The verbal root of the name is qhl, meaning "to gather" or "to assemble," hence, conveying the idea of "to call an assembly." The noun form points to the name "Qoheleth", perhaps as the title of one who gathers the assembly. This name not only draws attention to one who gathers but also the emphasis of the name in 12:9-14 is on one who gathers material and teaches. Thus, Qoheleth could be seen as one who gathers the people to address or teach them. He is literally the "assemblyman" who speaks for the person and who calls people to an assembly to speak to them. The English title of the book is derived

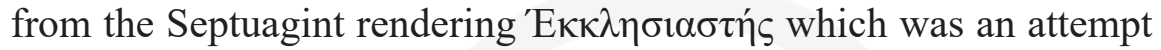
to render the Hebrew "qoheleth" into Greek using the analogy of

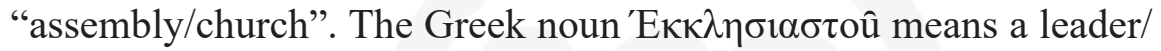
speaker of an assembly or a "Preacher". From the Hebrew, qoheleth, the term "Teacher" seems more preferable.

The Teacher who calls himself Qoheleth describes himself as "the son of David, king in Jerusalem." As a king, many have conjectured that he could be Solomon since he is the only king who ruled in Jerusalem and was a biological son of David. In 1 Kings $8: 1,22$, the root $q h l$ is used of Solomon "gathering" (yaqhêl) the elders of Israel and addresses the "assembly" (qěhal). However, these evidences are not strong enough to equate the author of the book to Solomon the King.

It has become increasingly accepted that the book is a postexilic one and was written around the fifth and third centuries BCE, looking at its unique grammar and syntax but Solomon lived around the ninth century. Other linguistic reasons have been given. In fact, Martin Luther is believed to be the first strong voice that sounded that Solomon was not the author. Most scholars judging from the Hebrew language used in writing the text tend

${ }^{249}$ Some spell it "Qohelet." 


\section{THIS COPY IS NOT FOR SALE}

to date the book around the fifth century or within the Hellenistic period. ${ }^{250}$ Therefore, he was not Solomon. Brevard Childs does not mince words when he establishes that "there is almost universal consensus, shared by extremely conservative scholars, that Solomon was not the author of the book." ${ }^{251}$ In the words of RBY Scott, there is of course no possibility that the Solomon of history composed this book ... The ascription of Wisdom sayings to Solomon was a literary convention. This is proved beyond question by the book known as 'The Wisdom of Solomon' in the Greek Bible (and in the English Apocrypha), which was written in the first century B.C. in Greek for Greek-speaking readers. ${ }^{252}$

What is clear is that the author calls himself "Qoheleth" who stands in the traditions of Solomon - someone to be seen as a Solomonic figure: wealthy, wise, and with great authority. If there is no personal name like Qoheleth as evidenced in the book, then he has succeeded to make himself anonymous. Some scholars argue that the anonymous author called himself "son of David, king in Jerusalem" (1:1; cf. vv. $12,16 ; 2: 9)$ to give his book a ring of authority as having been written in the tradition of Solomonic wisdom. It has been advocated that he only used Qoheleth to conceal his identity. ${ }^{253}$ Craig Bartholomew argues cogently that "Qoheleth" is thus a kind of nickname for the central character of the book who tasked himself to gathering wisdom for the people and now has been presented to us. In fact, it is not clear whether we are to think of Qoheleth as a historical person who live or as an imaginative character. The literary nature of Ecclesiastes means that Qoheleth may be a fictional construct by means of which the narrator presents his teaching. However, the narrator's comments about Qoheleth in 12:9-14 incline towards the view that Qoheleth is most probably a historical person. ${ }^{254}$

\footnotetext{
${ }^{250}$ For a simplified detail on the arguments of the author, see Barton, The Book of Ecclesiastes, 21,22; Seow, "Beyond Mortal Grasp: The Usage of Hebel in Ecclesiastes," ABR 48 (2000): 1-16.

${ }^{251}$ Brevard S. Childs, Introduction to the Old Testament as Scripture (Philadelphia: Fortress, 1979), 582.

${ }^{252}$ Scott, Proverbs \& Ecclesiastes, 195-196.

${ }^{253}$ E.J. Young, An Introduction to the Old Testament (Grand Rapids: Eerdmans, 1960)

${ }^{254}$ Craig G. Bartholomew, Ecclesiastes (Grand Rapids: Baker Academic, 2009), 103-104.
} 


\section{Biblical Wisdom as an Opportunity to make decisions}

Poetry is one of the strong vehicles that carries and transmits wisdom. Poetic speech has an inherent capacity to make a person wise. The artistic elements and deep poetic representations of the author made up of voice, imagery and dramatic effects speak a lot to shape life and behaviour. The poet opens opportunities for hearers to give ear to what is in store, and the one blessed with wisdom to make wise choices. The poetic voice of the sage undoubtedly remains the spectacular strength of the book of Ecclesiastes. How strange is it therefore that some commentators would consider the writer of Ecclesiastes as a disillusioned man! How can a disillusioned person teach a person to become wise if the book of Ecclesiastes is scripture?

Significantly, the book of Ecclesiastes is a useful companion of life that draws from narrative poetry, lyrical poetry and dramatic poetry with short, pithy proverbs unlike what is found in the book of Proverbs, which usually comes with short, pithy, terse statements. Some parts are folk wisdom, story-like and argumentative. For example, Ecclesiastes 3:1-11 is commonly held to be lyrical poetry, and can be captured as a song. The cultural settings within which wisdom thrived seemed to be the teaching spaces, homes, institutions, and public gatherings. In these settings, timeless views were propounded to deal with life's basic issues. ${ }^{255}$ These styles are pedagogical in nature. One can learn from these styles.

Beyond the capabilities of style, biblical poetry comes out forcefully when read for its beauty and "texture." In the words of Jennifer Parkhurst, "Like poetry in other traditions, biblical poetry employs techniques for conveying meaning beyond the literal sense of the words, putting across the poem's message more effectively, make it easier to set to music and remember, and entertaining or moving its hearer." ${ }^{256}$ As such, encountering the flow of words and the tenor of the speech makes it easier to move the hearer right from

\footnotetext{
${ }^{255}$ Samuel J. Schultz \& Gary V Smith, Exploring the Old Testament (Wheaton, Illinois: Crossway Books, 2001), 127.

${ }^{256}$ Jennifer T. Parkhurst, "The Conventions of Biblical Poetry: A Brief Introduction to the devices and Characteristics of poetry in this biblical genre"

https://www.myjewishlearning.com/article/the-conventions-of-biblical-poetry/
} 


\section{THIS COPY IS NOT FOR SALE}

the marrow to the outer flesh, shake the seats of traditions, and drive the sinews of motion.

James Crenshaw posits that there are generally about four major kinds of sapiential teachings: proverbs, parables, wise saying and riddles. ${ }^{257}$ Qoheleth uses all these four and highlights in addition aphorisms, frame narratives, fictional royal autobiography, and dramatic sermons. He uses various figures of speech, disputation, and hymn type addresses. In all, Qoheleth shows how possible it is to be a man of wit and eloquence.

Ecclesiastes is part of the Christian Scriptures and canon. It is a gift from God to humanity - sacred and inspiring. The proverbs, parables, wise sayings and riddles are all frames from the viewpoint of a faith community. Our lack of appreciation of the book does not make it worthless or meaningless. The wise people of the ancient world chose to reflect on life and spoke as they saw it so it it may enrich their faith. They drew from the accumulated wisdom of generations of faithful women and men who had wrestled to live lives of integrity, lives of wisdom to admonish the upcoming ones even to the present generation. Trying to explore the Christian spirituality of the poet will certainly add much frustration to the interpreter. The present generation may see the proverbs, riddles, contradictions, and more specifically the disjointed sections to be a problem. This is partly because of prejudices. The book does not meet expectations and the architecture prevents one from reading the book as a linear story. Moreover, the repeated concept of hebel "vanity", which features prominently in the book is a very elusive terminology. Many interpretations have been given to the word hebel like wind, breath, vapour, meaningless, etc. True to the nature of hebel, the search for meaning in the book can be a meaningless journey. It can be like chasing after the wind. This does not mean that there is no meaning to everything in life. In fact, the writer finds some meaning in God, work, wealth, enjoyment, and fear of God despite the mind-boggling issues that surround all these themes.

${ }^{257}$ Crenshaw, Old Testament Wisdom, 32. 


\section{THIS COPY IS NOT FOR SALE}

\section{Some Themes in the Book}

Let us turn to some of the messages of the book of Ecclesiastes.

\section{a) Hebel "vanity"}

Qoheleth presents his views on wisdom framed by the Hebrew catchword "hebel". The Hebrew phrase, hăbêl, hăbālim "vanity, O vanity" easily qualifies to be the trademark of Qoheleth. The English Bible following Jerome's Vulgate generally translates hebel as "vanity", connoting something that represents "breath" or "vapour". To assume that the use of the word "vanity" means something that lacks value will be farfetched. Michael Fox has convincingly stated that no single English word can capture the exact meaning of hebel as Qoheleth uses it. ${ }^{258}$ Each usage of the word hebel in Ecclesiastes presents a particular thought but it would be unfair to translate meaning alone by using different English expressions and not consider the artistic beauty of the trademark.

Although the Greek Septuagint (LXX) uses a variety of terms in other books to translate the word hebel as кعvó $\varsigma$ ('empty',

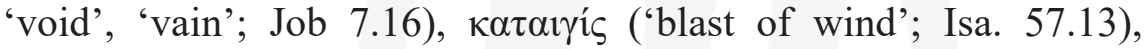

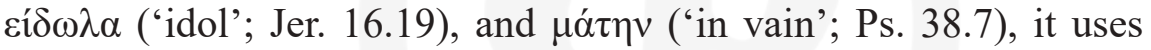
only $\mu \alpha \tau \alpha i o ́ \tau \eta \varsigma$ ('emptiness', 'transitory', 'vanity') to translate hebel in the book of Ecclesiastes. In the English Bibles, the word hebel has been translated variously like "false" (Jer 10:3), "breath" (Job 7:16; Ps 38:5; Isa 57:13), "nothing” (Jer 16:19); “empty” (Job 35:16; Ps 62:11; Isa 30:7); “vapour” (Prov 21:6); "worthless” (Jer 10:15; 51:18).

Since what Qoheleth sought to establish does not mean something useless, worthless, without value or false, the argument has been to use appropriate alternatives for each case rather than the word "vanity" in the book of Ecclesiastes. Unfortunately, that has not been found useful. In general, the meaning of the word hebel has been the concern. Seow suggests "beyond mortal grasp," to show that hebel means that which cannot physically or intellectually be grasped or controlled by humanity. ${ }^{259}$ Michael Fox observes that the Hebrew

\footnotetext{
258 Fox, Qoheleth and His Contradictions, 31.

259 Choon-Leong Seow, Ecclesiastes, AB, 18C (New York: Doubleday, 1997).
} 
hebel is used in the following ways in the book of Ecclesiastes: ${ }^{260}$ 1. Human behaviour

(a) Toil and its products: homo fabens

(b) Pleasure: homo ladens

(c) Wisdom: homo sapiens

(d) Speech: homo loquens

2. Living beings and times in their lives

3. Death

4. Divine behaviour - events of this world

(a) Divine justice

(b) Everything

All these categories cannot be taken as falling within the sense of "vanity" or "meaningless". Others suggest the translation "breath", ${ }^{261}$ "enigmatic" or "incomprehensible", 262 "absurd", 263 "transience."264

Certainly, hebel is a metaphor that takes more than ordinary minds to understand. Qoheleth speaks like a wise man and it take the wise to understand. The Builsa proverb is apt to quote here: Gwom gwomda ne a pagedo; bi a yam soaba yoalen wegese (lit. "words are spoken with their shells; it takes the wise who is able to peel them to understand").

More so, the use of the Hebrew kol "everything", "all" only fits within the setting that Qoheleth sought to explore and not "everything" there is in the world. Thus, one need not overgeneralize what Qoheleth seeks to say. The strategies in the use of these metaphors and selection of words combine to become a forceful tool to persuade the hearer about the speaker's conclusions.

Qoheleth's words may seem pessimistic, as if everything he

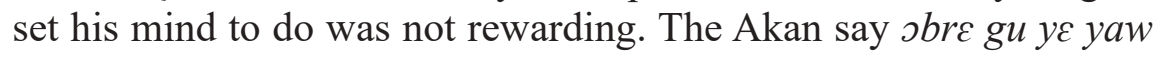

\footnotetext{
${ }^{260}$ Fox, Qoheleth and His Contradictions, 38.

${ }^{261}$ Scott, Proverbs \& Ecclesiastes, 209.

${ }^{262}$ Bartholomew, Ecclesiastes, 106.

${ }^{263}$ Michael V. Fox, “The Meaning of Hebel for Qohelet," JBL 105 (September 1986): 411; A. Schoors, Ecclesiastes, HCOT (Leuven: Peeters, 2013), 38-46.

${ }^{264}$ D.C. Fredericks, Coping with Transience: Ecclesiastes on the Brevity in Life (BS 18 (Sheffield: JSOT Press, 1993); R. L. Meek, "The Meaning of HBL in Qohelet: An Intertextual Suggestion," in The Words of the Wise are Like Goads: Engaging Qohelet in the 21st Century, eds., Mark J. Boda, Tremper Longman III and Cristian Rata (Winona Lake: Eisenbrauns, 2013): 241-256.
} 


\section{THIS COPY IS NOT FOR SALE}

(lit. working in vain is pathetic). That is to say, a fruitless action can never be satisfactory or rewarding. Qoheleth, however, achieved so much and they have been preserved for us as scripture.

\section{b) God is the foundation and controller of all}

Qoheleth says that his task was to search for meaning knowing that many things are not meaningful. Meaning, from Qoheleth, is founded only in relation to who God is and how God controls everything. Qoheleth's argument seems to portray that he could not fully understand who God is; at least no human being can fully know God. His inability to know God makes him conclude that it is hebel to know who God is. To understand vanity (hebel) in this case as "meaningless" to know who God is will be most unfortunate. That is not what Qoheleth teaches. Hence the translation "meaningless" does not fit his idea about search for who God is. What Qoheleth seeks to establish is that knowing who God is can be frustrating. In the words of Derek Kinder, "This incomprehensibility is dismaying for the thoughtful secularist, but not for the believer."'265

John Mbiti points out a similar thought pattern among Africans when he says that the various stories about who God is in African thought shows clearly that the nature of God escapes human comprehension. ${ }^{266}$ "In the case of God, people might know some of His activities and manifestations, but of His essential nature they know nothing. It is a paradox that they 'know' Him, and yet they do not 'know' Him; He is not a Stranger to them, and yet they are estranged to Him; He knows them, but they do not know Him." 267 The way Africans describe God is at best a metaphorical reflection; whether it is a misrepresentation or not, an image that is distorted or clearly defined, it is still God. The quest to be accurate in describing God never crosses the mind of the African. Qoheleth avoids going to the extent of describing who God is because it is meaningless to do so. Mbiti goes further to say, "It is to be noted also

\footnotetext{
${ }^{265}$ Derek Kidner, A Time to Mourn, and a Time to Dance: Ecclesiastes and the Way of the World (New York: IVP, 1976), 39.

${ }^{266}$ John Mbiti, African Religions and Philosophy (London: Heinemann, 1979), 38.

${ }^{267}$ Mbiti, African Religions and Philosophy, 35.
} 


\section{THIS COPY IS NOT FOR SALE}

that ultimately everything we say about God is in one way or another anthropomorphic, since it is expressed in human terms and human thought forms. Man[kind] does not know the language by which God describes Himself. Whatever mental picture we make of God, it is at best a human image." 268

God can only be understood as One beyond human grasp. Crenshaw seems to make the point clear about Qoheleth's view about God saying: "The careful reader will have noted that Qoheleth seems to know far more about God than his theology of divine mystery allows. In truth, he frequently makes assertations about God's will and activity despite the protestations about God's hiddenness."269 Hence, the fact that God is mysterious offers a great opportunity to readers to appreciate what Qoheleth wants to teach.

For Qoheleth, the only meaning to life is to fear God. Roy B. Zuck has creatively highlighted the message of Ecclesiastes this way: (1) Ecclesiastes affirms faith only in Elohim and all of life is under divine appointment and timing (2) the burden on humanity as well as the opportunity to enjoy food and work, wealth and possessions and honour are all from God and cannot be altered (3) every act, whether overt or hidden, good or evil will be judged by God. ${ }^{270}$ It is the wise who fear God and do not trust on their own experience. The concept of fear has broad usage in biblical thought, ranging from the nuances of reverential awe and respect to crippling terror and fright. Fear as in its cognitive and affective sense also connotes obedience.

Biblical wisdom as a distinct literary work is founded on the premise of God who directs the affairs of humanity, and as such the relationship between humanity and God should be that of reverential fear. According to William P. Brown, "wisdom begins and ends with the self, in recognition that knowledge of God cannot be divorced from human knowledge of the self." ${ }^{271}$ God controls all aspects of human life to the extent that no human being can predict what God is about to do next. How God guides all activity does not need

${ }^{268}$ Mbiti, African Religions and Philosophy, 50.

${ }^{269}$ Crenshaw, Old Testament Wisdom, 139.

${ }^{270}$ Roy B. Zuck, "A Theology of the Wisdom Books and the Songs of Songs," in Biblical Theology of the Old Testament, ed. Roy B. Zuck (Chicago: Moody Press, 1991), 246-247.

${ }^{271}$ William P. Brown, Character in Crisis (Grand Rapids: Eerdmans, 1996), 3. 


\section{THIS COPY IS NOT FOR SALE}

practical explanations but Qoheleth sought to do so and ended with the conclusion that it is meaningless to embark on that task. The African believes that "A piece of iron can only become what the blacksmith says it should be." Even the practical aspects of life can elude human thinking. For instance, why do people eat to become satisfied but sometimes never get satisfied? Biblical wisdom therefore is theoretical and also practical. At least, the wise people, through careful observation of how things work, general principles of what is accepted as right and wrong, and expectations in daily life, make wisdom very significant. ${ }^{272}$ Wisdom primarily focuses on practical, successful, joyful, moral living, analyzed through experience and not particularly with special revelation.

Qoheleth has his own unique way of expressing the word of God. He presents truth as a literary style, focusing on terse language, compact ideas, brevity of words but yet still expressing religious truth. To assert the catch phrase - "meaningless, O meaningless! Everything is meaningless" - is a style to make the reader sit up. Wisdom cannot be meaningful if it excludes knowledge of God. Therefore,Qoheleth's propositions are not literal, for Qoheleth affirms meaning of life only that it is located in God's plan of action. Mbiti also establishes that, in African thought "God is not blamed for calamities, misfortunes and sorrows which strikes man[kind]. He is brought into the picture primarily as an attempt to explain what is otherwise difficult for the human mind; an explanation which also serves to comfort those stuck by the particular form of suffering." 273

Qoheleth does not say that God has hidden all things completely from human knowledge. He affirms human ability "to see" $(2: 24 ; 8: 10,17)$ and "to know" $(3: 14 ; 8: 12)$ all these facts of life. He researched but puts it that one need not put his or her trust in research. He calls for enjoyment of life, even with food, drink and music and one's own wife but establishes that God is watching how one goes about enjoying. These, rightly put, fall under a sarcastic call to encourage a God-centered worldview.

\footnotetext{
${ }^{272}$ R. Laird Harris, Gleason Archer, and Bruce Waltke, Theological Wordbook of the Old Testament, 1 (Chicago: Moody Press, 1980), 283.

${ }^{273}$ Mbiti, African Religions and Philosophy, 45.
} 


\section{THIS COPY IS NOT FOR SALE}

Qoheleth in the closing of the book, uses language to articulate strong faith and theology; if everything is not as it is supposed to be, then fear God and worship God - that is the true meaning of life: "Now all has been heard; here is the conclusion of the matter: Fear God and keep his commandments, for this is the duty of all mankind" (Eccl 12:13). Mary-Jane Rubenstein goes too far to aver that,

Qoheleth depicts a Deity that defies categorization, a God who is transcendentally remote and seemingly indifferent yet also generous, if discriminatory, when it comes to granting joy, as we shall see. Qoheleth's God has set limits to human discernment yet instilled in human beings the capacity to be painfully aware of those limitations. ${ }^{274}$

Certainly, God has a purpose for each person. Sometimes the tendency is to look over our shoulders to see what God is doing in the life of others and wish ours is the same. It is not simply that God is so transcendent that is why we do not understand who God is. It is also that God is so immanent that we hate to look closely at what God is doing. It is possible, based on his allusion to the facts about human knowledge of God and how God controls the life of humanity to lead people in cowardly fear. No! It is godly fear that maters, for it draws us to accept whoever God is in worship. After all, Qoheleth affirms that there is meaning in life - it is in the fear of God. Such a call for worshipping God is not founded on abstract refection but on practical reverence and relationship with the Creator, following what God has given in our world.

\section{c) The Necessity of Wisdom}

The sages promoted the theological principle that wisdom affords one to live a meaningful life.Wisdom has its source in one's attitude of respect and reverence for God. In Israel, wisdom afforded a very practical understanding of life, and made one make decisions ideal for and about life. For one to live righteously according to the covenant, trusting in YHWH alone to be the source of help and strength in every situation, and to maximize pleasure in ${ }^{274}$ William P. Brown, Wisdom's Wonder: Character, Creation, and Crisis in the Bible's Wisdom Literature (Grand Rapids: Eerdmans, 2014), 163. 


\section{THIS COPY IS NOT FOR SALE}

living, the person needs wisdom.

The Akan term nyansa "wisdom" is made up of two words: nya (get) and ansa (before), thus connoting that it is a virtue one must acquire before everything can be done well. No one can be successful in life without first acquiring wisdom. Equally so, no one can go through failure without the use of "wisdom". Both the wise and the fool make mistakes (7:20) and a little folly can pollute and outweigh any amount of wisdom (10:1). Being wise of getting wisdom does not mean one cannot make mistakes in life. In the words of Edwards Curtis, "Risks and uncertainties in the world are not always related to folly; some are inherent in life. Risks are a part of necessary activities like building or working in the field, and while wisdom can significantly reduce these risks, wise people cannot always avoid unfortunate consequences." 275

The poor can be wise (4:13) as well as the rich, even though the wisdom of the poor is despised (9:16). Wisdom makes a person more powerful than ten rulers (7:19). However, there are certain aspects of life in which the wise does not have advantage over the fool (6:8). Interestingly, Qoheleth mentions that, to the wise and the one God favours, wisdom is assigned, and to the fool the task of gathering and collecting "wisdom" to hand over to the wise $(2: 26)$. Again, wisdom cannot insulate a man from the trap of a wicked woman; only the favour of God does (7:26).

As long as wisdom is a divine gift, no human being can claim to have possession of it except God who grants it (8:17). He says, "All this I have tested by wisdom; I said, 'I will be wise'; but it is far from me. That which is, is far off, and deep, very deep; who can find out" (7:23-24). This does not mean that wisdom is unsearchable and unachievable; rather becoming anxious to be wise is futility. Wisdom is a divine breath in the mortal human being's nose. No one can control what goes in and what comes out. It is too wonderful to be reduced to something that shares equal abilities with human beings. The Yoruba say, Ejighi akwa ebitere ebite agbasi egwu ike (lit. "you do not dance energetically when wearing borrowed clothes"). Since

${ }^{275}$ Edward M Curtis, Ecclesiastes \& Song of Songs (Grand Rapids: Baker Books, 2013), 95. 


\section{THIS COPY IS NOT FOR SALE}

a human being cannot simply lay claim to what is divine, it calls for circumspection. The best way to appropriate wisdom is to depend on the Giver who gives freely.

The wise sayings and proverbs in the book of Ecclesiastes offer opportunities for human beings to know what lies ahead of them in this earthly life so that life's path can be traversed with wisdom. Qoheleth does not claim that a human being cannot be wise even though he says that God has made it difficult for human beings to get to wisdom. The Akan call human beings nyimpa. This is from two words: nyim meaning "knowledge" and pa meaning "good". On the one hand it could mean that the human being knows what is good. On the other hand, it could mean that the human being must know what is good. The analogies and metaphors in the language of Qoheleth stress on apparent randomness of nature, unpredictability of the future, and limitations of human beings. Wisdom is no exception. One cannot pinpoint the exact outcome of a wise move. However, he has moved out to "search" for wisdom and it is imperative for all to "search" for wisdom using the right way.

Qoheleth is aware of the important events that take place in every space of time in land and sea, earth and heaven. He has observed how nature works, like the sun (1:5), wind (1:6), streams and sea (1:7). He has seen the movements of birds (12:4) and grasshoppers (12:5). He has an idea about agricultural cycles of ploughing, planting and harvesting (3:2) and encourages work. He talks about dreams (5:7) sleep $(5: 12)$ and death $(3: 18-22 ; 7: 1-4 ; 9: 5-6,10$ cf $4: 2 ; 8: 7 ; 11: 5)$. The rich and the poor, the young and the old as well as men and women are all addressed. He abhors tyranny, oppression $(3: 16 ; 4: 4$; $5: 8 ; 7: 7)$, and bribery $(7: 7)$. Not only is the author concerned with people who do manual labour but also technocrats and intellectuals, calling for an appreciation of the future for all its worth to inform the now, taking advantage of limitations rather than to be in endless anticipation. Such deep knowledge requires a pause, not putting on the breaks but slowing the game so that the rhythm of the steps can be evaluated. Although he is concerned about things "under the sun", the view that God exists and controls all affairs point to what happens 


\section{THIS COPY IS NOT FOR SALE}

in the heavenly realm. Taking a pause to acknowledge all these opens one to wisdom. Timothy J. Sandoval contends that the sages used wealth as an analogy "to underscore the desirability of the way of wisdom generally and the values and virtues associated with that way." 276

It is no wonder that Qoheleth struggles with how human beings can make the best out of every situation. Given the fact that he is unable to pinpoint the right "time" and "season" for everything, people should live their life to the fullest of their abilities. The Akan says, obra wo bo ("life is lived"). The saying literally points out that life must be played out like a game or like cracking a seed to get to its kernel. Most often, one must strategize and outplay the other to win. Qoheleth clearly shows how one can outplay all others and every circumstance, thrive on gifts received by God to unleash new ideas that many dare to reflect on. Robert Alter is right in defining an artist "as a person who thrives on realizing new possibilities within formal limitations." 277 What new possibilities can be gleaned if Ecclesiastes offers such a path to wisdom?

Qoheleth challenges all with his highly reflective inquiries. Christianity has thrived on faith - believing that which is not seen. The Enlightenment, alongside modern and postmodern interpretations especially in science and philosophy, has challenged faith but not to the extent this author of Ecclesiastes has done. No longer should people be satisfied with what is traditional, what they hear, see and experience in the Christian journeys.No longer should people refrain from searching out meaning. Qoheleth has set an example by searching, asking, probing, researching, answering, and concluding by calling all to fear God. Qoheleth makes a clear distinction between faith and works as well as "intelligence" and "wisdom." Qoheleth approaches his discussions from the practical side of life and concludes that there are limitations in faith and works, as well as in intelligence and wisdom. To him, one can accumulate factual knowledge but the inability to apply that knowledge makes

\footnotetext{
${ }^{276}$ Timothy J. Sandoval, The Discourse of Wealth and Poverty in the Book of Proverbs (Leiden: Brill, 2006): 68

277 Robert Alter, The Art of Biblical Poetry (New York: Basic Books, 2011), 24.
} 
a person unwise. The intelligent can still be a fool, whereas the intellectually limited can still be considered as wise. No wonder the Akan say, adze a $\supset y \varepsilon$ dew biara, bonwema bata ho (lit. every sweet thing has bitterness attached to it). Qoheleth claims that it is difficult for one to be wise because God has made it so. Wisdom can be beyond human grasp but it is good to be wise anyway for wisdom is better than folly. ${ }^{278}$ Qoheleth seems to be saying why worry your head trying to find meaning when your duty is to fear God and keep His commandments. In the words of Peter Enns,

Qohelet is wise, to be sure, and his words hurt. What do you expect from wise sayings? But remember, my son, in the midst of any sort of similar stresses and doubts you yourself might experience, no matter how unnerving and "unorthodox" a question may come from your lips, no matter how much you are frustrated and even angry with God himself, remember this: fear God and keep his commandments. ${ }^{279}$

He certainly does not leave readers downhearted and gloomy by his submissions. True, life at times seems like a jigsaw puzzle. Not all can find the right pieces to fit the puzzle. In fact, he is sure that there are no pieces missing. Hence, Qoheleth gave a realistic view of life, a view that admits difficulties and deficiencies, inequalities and uncertainties, yet the two sides of the coin are distinct, and the way out is a positive recommendation to fear God.

Qoheleth may not be pessimistic or cynical after all, but brutally realistic. He particularly makes the reader confront the full and dreadful significance of death. Most people, whether or not they are religious, refuse to face what death really is: a calamity that nullifies the achievements of human life. He strips away the myths we use to shield ourselves from this stack fact about death.

\section{d) The Significance of Enjoyment}

Another key statement by Qoheleth that clearly distinguished the ${ }^{278}$ Proverbs constantly insists that fools see themselves as wise in their own eyes (cf Prov 3:5; 7:2; 8:11; $12: 5 ; 16: 2 ; 21: 2 ; 26: 5,12,16)$.

279 Peter Enns, “Ecclesiastes according to the Gospel: Christian Thoughts on Qohelet's Theology,"

Scripture \&Interpretation 2.1 (2008): 35. 
book as a positive manual of life is the call for humanity to enjoy life $(2: 24 ; 3: 12 ; 3: 22 ; 5 ; 17 ; 8: 15 ; 9: 1-12 ; 11: 8-10)$. No wonder, R. N. Whybray refers to Qoheleth as a "Preacher of Joy" and points out a key theme in the book that teaches how humanity should "enjoy to the full what good things God has given; and indeed this is what God requires of them." 280 Eunny Lee also looks at the structure of the book and admits that it can equally be seen in the motif of joy. She holds that:

Qohelet's initial commendation of enjoyment has the quality of a concession ("there is nothing better," 2:24); with each reiteration, however, the enthusiasm and urgency with which he presents his counsel of joy is heightened, until he breaks out into an effusive command to enjoy life at every possible moment (9:7-10), before the demise of human life makes such possibilities no more (11:7-12:7). The modulation of tone in these joy texts, in turn, governs the tone of the book as a whole. ${ }^{281}$

Similarly, Michael McCabe points out that the main hob that drives the message of the book of Ecclesiastes is enjoyment. He concludes his paper by saying: "Qohelet in summary form has exhorted us to judiciously and reverentially use and enjoy our divinely bestowed gifts. The primary thrust of his response focused on his Leitmotiv of enjoying life." 282

The call for enjoyment is not one that is founded on loose self-gratification. It is a call to appreciate what one can get; being content and grateful for what life offers. Eunny Lee makes a forceful submission that enjoyment from the perspective of Qoheleth is a clear positive statement, not to be consumed as if there is more but to appreciate what one goes through. ${ }^{283}$ She says,

The dominant culture constantly bombards the public with

\footnotetext{
${ }^{280}$ R. N. Whybray, “Qoheleth, Preacher of Joy," Journal for the Study of the Old Testament 23 (1982): 87-98. See also R. N. Whybray, Ecclesiastes, NCB (Grand Rapids: Eerdmans, 1989), 2. Emphasis original.

${ }^{281}$ Lee, The Vitality of Enjoyment in Qohelets' Theological Rhetoric, 17.

${ }^{282}$ Robert V. McCabe, “The Meaning of Ecclesiastes," Detroit Baptist Seminary Journal (Spring 1996): 112

${ }^{283}$ Lee, The Vitality of Enjoyment in Qohelets' Theological Rhetoric, 18.
} 


\section{THIS COPY IS NOT FOR SALE}

the message that to be human is to be a consumer. A full life is a life filled with more, and more is always accessible and attainable. Qohelet's ethic of enjoyment opposes precisely these excesses. It issues the warning that this cultural ideology is a tragic deformation of appropriate human longings; it denounces the inflated expectations and inordinate desires that plague and threaten human society. Qohelet's ethic of enjoyment, then, is a recuperation of the norm. Enjoyment is emphatically not about the pursuit of more-not even the pursuit of joy — but the glad appreciation of what is already in one's possession by the gift of God. It means that the human becomes free not to grasp, not to possess, not to know. ${ }^{284}$

The reason why one must enjoy and appreciate what comes is that everything is a gift of God. Failure to enjoy is a way of telling God that what has been given is not enough. Certainly, a bird in hand is worth more than two in the bush. By being grateful, a person opens up for more kindness.

If one of the strongest recommendations of Qoheleth is to enjoy life then that is the best thing to do. By employing the Hebrew vocabulary simchah ("joy"), he argues that people can only enjoy if they relate with God. It is God who gives a person the opportunity to enjoy. No one can enjoy apart from God $(2: 24-26 ; 3: 13 ; 5: 18 ; 9: 7)$. Enjoyment is a "portion" (Heb: chalak) God gives to both the poor and the rich $(2: 10 ; 3: 22 ; 5: 17-20 ; 9: 9)$. In 9:1-2, Qoheleth calls all to enjoy seven things in life: food, wine, clothing, appearance, work of our hand, and our spouses. ${ }^{285}$ All these, the author claims, has been approved by God.

Enjoyment is for all. As the elders would say, "if you think you are too small to be noticed, go and sleep in a room which is full of mosquitoes." The Akan maxim goes, ketewa biara nnsua (lit. "no little thing is small") and nyia onya kakraba n'enyiwa so no, onya kese a n'enyiwa so (lit. "the one who appreciates it when given

\footnotetext{
${ }^{284}$ Lee, The Vitality of Enjoyment in Qohelet's Theological Rhetoric, 128.

${ }^{285}$ In the view of Addison Wright, the seven commands for enjoyment in vv. 7-9 counterbalances the seven negative traits of death in vv. 4-6. See Addison Wright, "Ecclesiastes 9:1-12: An Emphatic Statement of Themes," Catholic Bible Quarterly 77 (2015): 255, 256.
} 


\section{THIS COPY IS NOT FOR SALE}

Part Three. Understanding the Wisdom of Ecclesiastes

little will also appreciate it when much is given"). The Builsa proverb goes, fifika a zang chong kinla (lit. "a little is better than nothing"). As long as the poor can engage in some toil to earn something, he or she can be given the gift to enjoy, even if it is little food and wine. It seems modernity has influenced some to have negative impressions about traditional foods in Africa. This has made some Ghanaians not to accept what they have as a gift to enjoy; they prefer European and American foods but no one has disputed the richness of traditional food. One ought to eat and drink with pleasure $(2: 24-25 ; 3: 13 ; 5: 17$ 18). So Qoheleth commends enjoyment (8:15). Qoheleth adds that feasting is for strength and not for drunkenness (10:17). To enjoy so that one's strength can be improved may echo what the Akans say: yeronom nsa na yerefa adwen (lit. "as we are drinking, we are making decisions"). One must not engage in drinking for other reasons, especially knowing that the drink will affect one's health.

Incidentally, material wealth like houses, gardens, pools, farms, livestock, money, music and women (2:1-8) can not induce pleasure. These do not give lasting benefit $(2: 3,8,11 ; 4: 4-10)$. For Qoheleth, pleasure is good $(3: 12,22 ; 5: 17 ; 8: 15)$ but it can also be profitless $(2: 1,15)$ and does not give any advantage $(2: 11)$. God enables a person to consume his or her wealth. God enables either the rich or the poor to find satisfaction in pleasure. Some will have to leave their hard-won wealth for others who did not work for it to enjoy $(2: 18 ; 6: 1-2)$. Africans hold that "not all baboons that enter a maize field come out satisfied." At least some will be satisfied. Likewise, "the goat that cries the loudest is not the one who eats the most." People sometimes complain even when there is much and no justification to complain. Africans, for instance, have all the natural resources and the best organic food that the soil can produce. Yet they spend lots of time complaining, thereby losing sight of what God has given them to enjoy. They want what others have; they crave for "junk-food" elsewhere. For Qoheleth, it is worse off if the heir is a fool who will misuse what has been inherited (2:19). No wonder Europeans and Asians are scrambling for the rich resources in Africa, and Africans are cheerfully giving out to them the best on a silver platter. They in turn become rich and succeed in creating viruses that will be tested in Africa. 


\section{THIS COPY IS NOT FOR SALE}

In fact, Qoheleth praises wealth as a pathway to pleasure. He even goes as far to say, "money answers everything" (10:19). An African saying goes like "money can make both the wise and the fool to laugh. When they laugh, the fool rather forgets to close his/ her mouth." That is to say, there is a better way to enjoy and have pleasure and it takes a wise person to do what is acceptable.

The enjoyment motif may be seen as strongly linked to Epicurean philosophy. As Barton notes, there is a fragment in the Epic of Gilgamesh found in a tablet written around the Hammurabi dynasty which bears a similar thought. He adds that, "The eating and drinking, the enjoyment of one's labour, the cheerfulness, the delight in pleasure, the feeling that death ends it all - all these are contained in it. ${ }^{286}$ For the author, enjoyment is the only real advantage in life. Those who think that life makes sense do not really understand what goes on in life because life is unpredictable. Nevertheless, enjoyment is vanity. Elsewhere in 7:3 he sees vexation as better than laughter.

From another angle, Qoheleth may be seen as a realist or a hedonist. However, it needs to be affirmed that Qoheleth's enjoyment motif is a positive one and not that of unbridled hedonism. In the words of Addison Wright,

The enjoyment of which he speaks is not hedonism or a total dedication to pleasure seeking for its own sake. Qoheleth dismisses that in Eccl 2:1-11. Rather, enjoyment refers to foe ordinary and simple pleasures of life as they present themselves, and he views enjoyment as a choice to be made and strongly recommends it. ${ }^{287}$

No wonder, Qoheleth's call for enjoyment is closely linked with his faith in God; it is God who gives an individual the opportunity to enjoy. If God is permitting one to enjoy, what else can one do? John Mbiti's words are apt when he says that, "African image of the happy life is one in which God is among the people, His presence supplying them with food, shelter, peace, immortality or gift of resurrection, and a moral code." 288

286 Barton, Ecclesiastes, 38.

287 Wright, "Ecclesiastes 9:1-12: An Emphatic Statement of Themes," 251.

${ }_{288}$ Mbiti, African Religions and Philosophy, 98.

(C) Copyright 2020, Noyam Publishers | www.noyam.org 


\section{Conclusion}

Have you experienced a time when a drama comes to an end, but the voices of the actors still echo in your minds? There are times people walk away after the act and not the words, for words cannot end. We are not finished yet with Qoheleth the teacher. His voice still echoes through the chimes and in the hearts of the discerning. He is a preacher, not just an actor. He means to influence lives. The Akan say tekyercma mmporow (lit. the tongue does not decay). That is to say, what Qoheleth has said keeps vibrating and echoing, drawing new listeners and engaging new audiences. Words and speech do not have a life span; they are limitless and can linger on and on as long as it erupts in the memory. Significantly, not all has been said; the need to add to what has been said cannot be overemphasized.

It takes the one who feels the words, action and music to contribute to the on-going art. The one who knows supplies what to add. This is because words are a reflection of self; they tell who you are. They tell where you have been and where you have sat. It identifies those who have walked the path with you and supported you along the way.

In our contemporary African world where traditions and cultures are not given a prominent place in educational development, digging into our roots to recollect the proverbs of our forebears would help to build knowledge - know what it means, collectively or individually, to be a human being. Hence, there is a general need for sages in society, government, institutions, business and church. The sages are the ones who provide wise counsel for life endeavours.

The general crisis in contemporary Africa where traditions have been abandoned and the use of proverbs minimized in speech 
art comes from alienation from the self, the community and culture. A person who is not conversant with his or her own culture is lost. The grey hair which used to be a symbol of wisdom can be found on very young people yet with little to show. African preachers can learn from the way Qoheleth draws on cultural forms to make his message distinct.

Qoheleth the poet has spoken after reflecting on all that happens under the sun. The communicative power of using proverbs is an art; an emotional way of expression. In this art, the artist depended on the instrument of the self. Mastery in the art of speaking with proverbs comes with the development and mastery of the self. It does not come by chance nor is it natural. No one was born to be thrilling and master of voice and speech. It comes by searching; it comes by training. The long search by Qoheleth should motivate our search in the African pot where narrative, folklore, music and poem form the ingredient of the soup.

African drama is not highly comical per se. It teaches and informs. It celebrates diversity. It comes as words of wisdom and plays an important role of teaching values and character traits. It clarifies how people think, come by their expectations, and how to live a meaningful life. It shows how to make decisions in life, especially difficult and responsible ones (as well as those decisions that lead to negative outcomes). It teaches how to be careful in life so that one does not fall for the tricks of Ananse. Wise people are not afraid of what others might think or say. Good orators and actors are not afraid to speak their mind; they exert a lot of influence on people. In a sense, one can say that the lack of good actors is affecting the life of the church and society.

Narrative art is what the wise can offer. Reading the book of Ecclesiastes as drama has offered an opportunity to show how to think through decisions. This can be off the limits of logic for the power of dramatic art is satiation.

Although society needs people with values, credibility, visions and perspectives, those who speak through reflections to 
remind all about the past and share generally opinion to show the way - wise people who are able to inspire the hearts of all to take the right decisions - so that it is easy to retrace one's steps if they strayed matter. Wise people are prompted when words and actions that mean so little to the general public are spoken and are able to reflect within popular consciousness to create heightened emotional tensions that are creative. Such dramatic narratives provide both entertainment and knowledge that are platforms for self-reflection. It says what needs to be said through a different lens. It helps the gloomy self to be high in spirit. It invites all to celebrate the world through performance. Truly, African drama incites and invites, for further discussion and for fulfilment.

What do you say? 


\section{Bibliography}

Asimeng-Boahene, Lewis. "Mirror of a People: The Pedagogical Values of African Proverbs as Cultural Resource Tools in Content Area in Social Studies Classrooms." In African Traditional and Oral Literature as Pedagogical Tools in

Content Area Classroom, ed. Lewis Asimeng-Boahene and Michael Baffoe. Charlotte, NC: Information and Age Publishing, 2014.

Alter, Robert. The Art of Biblical Poetry. New York: Basic Books, 2011.

Attridge, Derek Poetic Rhythm: An Introduction. Cambridge:

Cambridge University Press, 1995.

Bartholomew, Craig G. Ecclesiastes. Grand Rapids: Baker Academic, 2009.

Barton, George A. A Critical and Exegetical Commentary on the Book of Ecclesiastes, International Critical Commentary. Edinburgh: T\&T Clark, 1959.

Brown, William P. Character in Crisis. Grand Rapids: Eerdmans, 1996.

"Whatever your Hands finds to Do": Qoheleth's Work Ethic." Interpretation (2001): 270-284. Wisdom's Wonder: Character, Creation, and Crisis in the Bible's Wisdom Literature. Grand Rapids: Eerdmans, 2014.

Brueggemann, Walter. Old Testament Theology: Testimony, Dispute, Advocacy. Minneapolis: Fortress Press, 1997.

The Message of the Psalms Augsburg Old

Testament Studies. Minneapolis: Augsburg, 1984.

Childs, Brevard S. Introduction to the Old Testament as Scripture. 
Philadelphia: Fortress, 1979.

Christianson, Eric S. Ecclesiastes through the Centuries, Blackwell

Bible Commentaries. Malden: Blackwell Publishers, 2007.

Crenshaw, James L. Old Testament Wisdom - An Introduction.

Atlanta: John Knox Press, 1981.

Curtis, Edward M. Ecclesiastes \& Song of Songs. Grand Rapids:

Baker Books, 2013.

Dhlomo, H.I.E. "Drama and the African." English in Africa 4.2

(1977): 3-8.

Durkheim, Emile. Division of Labor in Society. Illinois: The Free

Press of Glencoe, 1933.

Echeruo, M.J.C. "The Dramatic Limits of Igbo Rituals," in Drama and Theatre in Nigeria: A Critical Source

Book. Edited by Y. Ogunbiyi. Lagos: Pitman Press, 1981.

Enns, Peter. "Ecclesiastes according to the Gospel: Christian

Thoughts on Qohelet's Theology," Scripture \& Interpretation

2.1 (2008): 25-38.

Fox, Michael V. "The Meaning of Hebel for Qohelet," Journal of Biblical Literature 105 (September 1986): 409-427. Qoheleth and His Contradictions. Decatur, GA: Almond Press, 1989.

Fredericks, D.C. Coping with Transience: Ecclesiastes on the Brevity in Life. Biblical Seminar, 18; Sheffield: JSOT Press, 1993.

Grout, Donald Jay. A Short History of Opera, $2^{\text {nd }}$ edition. New York: Columbia University Press, 1965.

Harris, R. Laird, Gleason Archer, and Bruce Waltke. Theological Wordbook of the Old Testament, 1. Chicago: Moody Press, 1980.

Hrushovski, Benjamin. "On Free Rhythms in Modern Poetry" in

Style in Language. Edited by Thomas A Sebeok. New York:

The Technology Press of Massachusetts Institute of

Technology and John Wiley \& Sons, Inc, 1960.

Johnston, R.K. "Confessions of a Workaholic: A Reappraisal of

Qoheleth.” Catholic Biblical Quarterly 38 (1976):14-28.

Kanyaro, Musimbi R.A. "When Women Arise, The Earth Trembles." 
In Claiming the Promise: African Churches Speak, ed.

Margaret S. Larom. New York: Friendship Press, 1994.

Kidner, Derek. A Time to Mourn, and a Time to Dance: Ecclesiastes and the Way of the World. New York: IVP, 1976.

Lee, Eunny P. The Vitality of Enjoyment in Qohelets' Theological Rhetoric, BZAW 353. Berlin: de Gruyter, 2005.

Mbiti, John. African Religions and Philosophy. London: Heinemann, 1979.

McCabe, Robert V. "The Meaning of Ecclesiastes.” Detroit Baptist Seminary Journal (Spring 1996): 85-112

Meek, R. L. "The Meaning of HBL in Qohelet: An Intertextual Suggestion." In The Words of the Wise are Like Goads:

Engaging Qohelet in the 21st Century.

Edited by Mark J. Boda, Tremper Longman III and Cristian Rata. Winona Lake: Eisenbrauns, 2013.

Newport, John P. “Questions Ministers ask about Literature and Drama," Southwestern Journal of Theology 10 (1968): 3147.

Parkhurst, Jennifer T. "The Conventions of Biblical Poetry: A Brief Introduction to the devices and Characteristics of poetry in this biblical genre."

https://www.myjewishlearning.com/article/the-conventionsof-biblical-poetry/

Reitman, James S. "The Structure and Unity of Ecclesiastes." Bibliotheca Sacra (1997): 279-319.

Sandoval, Timothy J. The Discourse of Wealth and Poverty in the Book of Proverbs. Leiden: Brill, 2006.

Schoors, A. Ecclesiastes, Historical Commentary on the Old Testament. Leuven: Peeters, 2013.

Schultz Samuel J. \& Gary V Smith, Exploring the Old Testament. Wheaton, Illinois: Crossway Books, 2001.

Scott, R.B.Y. Proverbs \& Ecclesiastes: Introduction, Translation and Notes, Anchor Bible. Garden City: Doubleday \& Company, Inc., 1982.

Seow, Choon-Leong. "Beyond Mortal Grasp: The Usage of Hebel in 
Ecclesiastes," Austrailian Biblical Review 48 (2000): 1-16. Ecclesiastes, AB, 18C. New York: Doubleday, 1997. "Theology when Everything is out of Control." Interpretation (2001): 237-249.

Vos, Cas J.A. Theopoetry of the Psalms. London: T \& T Clark, 2005. Whybray, R. N. Ecclesiastes, New Century Bible Commentary.

Grand Rapids Eerdmans, 1989. "Qoheleth, Preacher of Joy," Journal for the Study of the Old Testament 23 (1982): 87-98.

Wright, Addison. "Ecclesiastes 9:1-12: An Emphatic Statement of Themes." Catholic Bible Quarterly 77 (2015): 250-262.

Wright, J. Strafford. 'Ecclesiastes," in The Expositor's Bible

Commentary - Volume 5, ed. Frank E. Gaebelein. Grand Rapids: Zondervan, 1991.

Young, E.J. An Introduction to the Old Testament. Grand Rapids: Eerdmans, 1960.

Zuck, Roy B. "A Theology of the Wisdom Books and the Songs of Songs." In Biblical Theology of the Old Testament. Edited by Roy B. Zuck. Chicago: Moody Press, 1991. 


\section{ABOUT AUTHOR}

Mark S. Aidoo is senior lecturer in Old Testament studies and Hebrew at Trinity Theological Seminary, Legon Ghana. He is the General Secretary of West Africa Association of Theological Institutions (WAATI), and a member of Ghana Association of Biblical Exegetes (GABES). He is the author of Shame in the Individual Lament Psalms and African Spirituality published by Peter Lang. His research interests relate to the Hebrew poetry, Old Testament interpretation, African Spirituality, Leadership, and Preaching. Mark is also an ordained minister of The Methodist Church Ghana and serves as the Probationer's Secretary. 